\title{
A placebohatás és az alkohol
}

\author{
BODNÁR VIVIEN ${ }^{1}$ - NAGY KRISZTINA² - CZIBOLY ÁDÁM ${ }^{3}$ \\ - BÁRDOS GYÖRGY* \\ ${ }^{1}$ Eötvös Loránd Tudományegyetem, Pszichológiai Intézet, \\ Pszichológiai Doktori Iskola, Budapest \\ ${ }^{2}$ Budapesti Múszaki Egyetem, Kognitív Tudományi Tanszék, Budapest \\ ${ }^{3}$ Eötvös Loránd Tudományegyetem, Pedagógiai és Pszichológiai Kar, Egészségfejlesztési \\ és Sporttudományi Intézet, Budapest
}

(Beérkezett: 2017. május 10., elfogadva: 2017. október 10.)

Elméleti háttér: A placebohatás a mindennapi élet számos területén tetten érhető, amikor valamely pszichoaktív szerhez kötődő elvárás vezet szubjektív és fiziológiai változásokhoz, hatóanyag jelenléte nélkül. Cél: Szeretnénk feltárni, hogy az alkohol és a hozzá kapcsolódó elvárások - a társas hatásokkal együtt, illetve azoktól elkülönítve - hogyan befolyásolják a résztvevőket, különösen a memória, az egyensúly, és a szubjektív testi-lelki állapot kapcsán, az alkoholos, alkoholosnak vélt, illetve alkoholt nem tartalmazónak gondolt koktélok elfogyasztása esetében. Módszerek: Kiegyenlített placebo elrendezésben, társas és egyéni feltételekben vizsgáltuk a rövidtávú memória, az egyensúlyérzék, és a szubjektív testi-lelki állapot alakulását, szó lista visszaidézése, „,részegállás” megtartása, és egy 17 melléknévpárból álló szemantikus differenciál skála felhasználásával. Eredmények: A szubjektív testi-lelki állapot mérése során feltárt szociális viselkedések és testi tünetek faktor mentén a vizsgált csoportok eltérő mintázatot mutattak: a résztvevők a manipulációnak megfelelő elvárásaik mentén számoltak be szubjektív tüneteikről, amelyeket a csoporthatások tovább erősítettek. A vizsgálatban mind egyéni, mind pedig társas fogyasztás esetében sikerült kimutatni az elvárások által indukált klasszikus placebohatást a megtévesztett, alkoholt valójában nem fogyasztók körében. Az alkoholt és a placebót fogyasztó csoport sem a szociális viselkedések, sem a testi tünetek, sem pedig az egyensúly romlása mentén nem különbözik szignifikánsan egymástól. A csoportos alkoholfogyasztás tovább erősíti az alkohol valós vagy vélt hatásait az egyensúlyra és a memóriára. Következtetések: Kis mennyiségú alkohol fogyasztása esetében az alkohol indukálta állapot kialakulásáért az etanol csak részben felelős, az alkoholfogyasztást követő pszichés és fizikai változások jelentős része - elvárások és a társas közeg által meghatározottan - a placebohatásra vezethető vissza.

Kulcsszavak: alkohol, placebo, kiegyensúlyozott placebo elrendezés, elvárás, társas hatás

\footnotetext{
* Levelező szerző: Prof. Dr. Bárdos György, Eötvös Loránd Tudományegyetem, Pedagógiai és Pszichológiai Kar, Egészségfejlesztési és Sporttudományi Intézet, 1117 Budapest, Bogdánfy Ödön u. 10/B. E-mail: bardos.gyorgy@ppk.elte.hu
} 


\section{Bevezetés}

A hétköznapi életben számos olyan jelenséget ismerünk, amelyek során valamely anyag hatását a szer kémiai jellemzői nem képesek teljes mértékig magyarázni. Gyógyszert bevéve a fájdalomcsillapító hatás rendszerint korábban jelentkezik, mint ahogy azt a szer felszívódása magyarázná, koffeinmentes kávé hatására is lehetünk éberebbek, és akár alkoholmentes sörtól is ittassá válhatunk (Köteles, 2014). Ezekben az esetekben a pszichoaktív szerek kémiai hatásán túl egy másik jelentős hatás is érvényesül, mégpedig az úgynevezett placebohatás. A hatás ellentéte, amikor valamilyen kémiai szer, például alkohol hatását elképzeléseinkkel módosítjuk, szintén a mindennapi tapasztalatok közé tartozik. Ittas, kábult állapotban lévő emberek feje pillanatok alatt "kitisztulhat”, amennyiben a helyzet megköveteli. Tehát elképzeléseink és elvárásaink alakítják részben, hogy hogyan reagálunk bizonyos pszichoaktív anyagokra. A szocializációval és tapasztalattal elsajátított, ittassághoz kapcsolódó elvárások (Fillmore \& Vogel-Sprott, 1996) társas környezetben erőteljesebben aktiválódnak, mint magányos ivás esetén.

A placebo szó a latin placere (tetszeni) igéból származik, jelentése „tetszeni fogok" (Webster's, 1997). A jelenség legszélesebb körben elfogadott definícióját Shapiro és Shapiro (1997; idézi: Cziboly \& Bárdos, 2003, 383. o.) alkották meg, amely szerint: „placebónak nevezünk bármely olyan terápiát (illetve bármely terápia összetevőjét), amit szándékosan vagy tudatosan használnak nem specifikus, pszichológiai vagy pszichofiziológiai terápiás hatása miatt; vagy amit feltételezett specifikus terápiás hatása miatt alkalmaznak egy betegnél, tünetnél vagy betegségnél, de nem fejt ki specifikus aktivitást a kezelt állapotra".

\subsection{Elvárások}

A placebohatás múködési mechanizmusának magyarázatára a kondicionálásos elmélet mellett az 1980-as években bontakozott ki a placebohatást magyarázni kívánó másik befolyásos elmélet, amely a személyek elvárásait helyezi a középpontba (Ross \& Olson, 1981). A kondicionálásos placebohatás mechanizmusa élettanilag jól magyarázható, az elvárásos placebohatás múködésmódja azonban még nem teljesen tisztázott. Az elvárásos placebo humánspecifikum, amely tudatosságot követel meg, hatását az elvárások okozzák, a háttérben pszichológiai magyarázatok feltételezhetóek, kialakulhat a hatóanyagot tartalmazó szer előzetes bemutatásának hiányában is, és az elvárások megszúnésével oltódik ki (Cziboly \& Bárdos, 2003; Köteles, 2014). 


\subsection{Az alkohol}

A placebohatás vizsgálata során többféle anyagot használnak, például koffeint, nikotint és alkoholt. Az alkohol placebójának alkalmazása több szempontból nehezebb, mint például más anyagoké, hiszen nehéz elhitetni a résztvevőkkel, hogy valóban alkoholt fogyasztottak, és az alkoholhoz nehéz jó placebót találni (Lachenmeier, Pflaum, Nieborowsky, Mayer, \& Rehm, 2016), azonban nem lehetetlen (Schlauch és mtsai, 2010).

Az alkohol szervezetre gyakorolt hatásait tekintve megkülönböztethetjük a szer farmakológiai hatását, amely depresszáns. A gátló hatás által leginkább az információfeldolgozás, a memória, a testérzékletek és a motoros teljesítmény érintett. Nagyobb mennyiségú fogyasztás esetén az etanol agysejtekre gyakorolt hatása révén akut intoxikációs tünetegyüttes figyelhetó meg. A farmakológiai hatáson túl kiemelt szerepe van az elvárásoknak, amelyeket alapvetóen a társas viselkedés mentén érhetünk tetten. A két hatás dózisfüggő, vagyis kisebb mennyiség esetében az elvárásoknak nagyobb szerep jut a farmakológiai hatások mellett, mint nagyobb dózisok esetén, ahol a szer kémiai hatásai dominálnak. Mind a két hatás mentén egyéni különbségek színezik a képet, a testösszetétel, a korábbi alkoholfogyasztási szokások, a nem és a genetikai örökség a farmakológiai mechanizmusokat (Morean \& Corbin, 2010), míg az egyénenként eltérő elvárások, gondolatok és attitúdök az elvárási mechanizmusokat moderálják (Köteles, 2014).

A farmakológiai hatásokon túl megemlítendőek az alkoholfogyasztáshoz kapcsolódó elvárások, amelyek alapvetően a tapasztalatok és a kultúra által közvetített értékek mentén alakulnak ki (Marlatt \& Rosenhow, 1980). Christiansen, Goldman és Inn (1982) hat elvárásokra vonatkozó tényezőt tártak fel az italfogyasztással kapcsolatban (úgymint: fizikai feszültség lazulása, aggódás csökkenése, személyközi hatékonyság növekedése, tapasztalatok varázslatos átalakulása, kellemességérzet fokozódása, szociálisemocionális viselkedés módosulása), amelyekből az első öt már az alkoholt még nem fogyasztó, fiatalabb populáció esetében is megjelent. Tehát az elvárások nagy része már a szocializáció során elsajátítható, más elvárások azonban csak az ivási tapasztalattal alakulnak ki, illetve ezek konzisztenciája és homogenitása is növekszik a személyes tapasztalat által.

Az alkoholfogyasztás tudata, és maga a fogyasztás a mindennapi életben elválaszthatatlan egymástól, a placebo mechanizmusok vizsgálatához azonban szükséges a farmakológiai és az elvárásos hatások elválasztása. Egyes szerzők (pl. Gundersen, Specht, Grüner, Ersland, \& Hugdahl, 2008; Marlatt \& Rosenhow, 1980) szétválasztották az elvárások és az etanol hatását és azt találták, hogy az előbbi, főleg társas ivás esetén a szociális viselkedésekre van hatással - például serkenti az antiszociális viselkedést -, míg az utóbbi 
hatással van kognitív és fiziológiai folyamatokra is - pontatlanságokat okoz az észlelésben és a motoros múködésben, növeli a szexuális arousalt, gátolja a memóriafolyamatokat, javítja a közérzetet, továbbá felerősíti a gasztrointesztinális érzékelést, hőhullámokat vált ki, és javítja a dinamikus perifériás észlelést (Connors \& Maisto, 1979; Vuchinich, Tucker, \& Sobell, 1979). Más szerzők pozitív irányú kapcsolatot találtak az alkoholfogyasztás és az intim/romantikus viszony kialakítására való hajlandóság (Tyler, Schmitz, Adams, \& Simons, 2016), a kockázatkereső viselkedés (Scalese és mtsai, 2017; Scott-Sheldon és mtsai, 2016), a fiatalok körében jellemző konform viselkedéshez köthető népszerűség (French, Balsa, Homer, \& Norton, 2011), továbbá a kapcsolattartás és a társas elfogadás érzésének növelése érdekében a közösségi oldalakon történő alkoholfogyasztással kapcsolatos tartalmak megosztásának gyakorisága (Barnes és mtsai, 2015; Geusens \& Beullens, 2016) között. Tovább árnyalja a képet az alkoholfogyasztás társas jellege: a szociális környezetben történő fogyasztás, az egyéni fogyasztással szemben, felerősítheti az intoxikációs tünetegyüttes kialakulását (Kirkpatrick \& Wit, 2013).

Az elvárásokat vizsgáló kutatások egy részében megfeleló placebo alkalmazása esetében az eredeti szerhez, vagyis az alkoholhoz hasonló reakciókat sikerült kiváltani a résztvevőkből, vagyis teljesítménycsökkenés és a szubjektív részegség tünetei voltak megfigyelhetőek (pl.: Bárdos, 2011; Nagy, Cziboly, \& Bárdos, 2007). Nagy (2008) kimutatta, hogy konkrét fogyasztás hiányában, csupán képzeleti úton is magasabb értékeket érnek el a résztvevők az alkoholos befolyásoltságot mérő szubjektív vizuális analóg skálán. Az elvárások és a placeboalkohol hatásainak vizsgálatára a balanced design, vagyis a kiegyensúlyozott kutatási elrendezés alkalmas, amelyben a résztvevők egy része valódi szert, alkoholt kap, másik részük placebót, majd fordítva. A csoportot két részre oszthatjuk aszerint is, hogy milyen információt kapnak az elfogyasztott ital tartalmára vonatkozólag (alkohol vs. placebo) (Marlatt \& Rosenhow, 1981).

Az eddigi kutatási eredmények alapján jellemző, hogy a kísérletben résztvevők többségének megítélése az instrukcióknak megfelelően alakul, vagyis akik alkoholt isznak, azok közül ittasabbak lesznek azok, akik jól tudják, hogy mit fogyasztanak, mint azok, akik az ellentétét feltételezik; és fordítva is, azok, akik alkoholnak vélik a placeboalkoholt, ittasabbak lesznek az alkoholtartalomra vonatkozó pontos információval rendelkezó társaiknál (Bárdos, 2011).

A vizsgálatok egy másik része (Fillmore, Mulvihill, \& Vogel, 1994) ennek ellentmondó eredményeket kapott, amelyet az úgynevezett fordított, vagy kompenzatorikus placeboválasz fogalommal magyaráztak. Vizsgálatukban alkoholt, koffeint, illetve ezek placebóját adták a résztvevőknek, pszichomotoros teljesítményt serkentô, illetve azt gátló elvárásokat kiépítve. A kof- 
fein esetében a kísérleti személyek teljesítménye az instrukcióknak megfelelően alakult, míg az alkohol esetében a hatás fordított volt: a serkentőnek beállított placeboalkohol rontotta, míg a teljesítményt gátlónak bemutatott javította a teljesítményt. A paradoxnak túnő jelenség hátterében a résztvevők motivációja állhat, miszerint azok, akik hátrányból indultak, hiszen az „alkohol" gátolta a teljesítményüket, kompenzálnak és még inkább törekszenek a jobb eredmény elérésére. Ez a kompenzatorikus jelenség nemcsak a placebo, de alkohol fogyasztása esetén is megfigyelhető (Fillmore \& Vogel-Sprott, 1996). Tehát az alkoholnak bizonyos dózisig ellen lehet állni, és a fiziológiás folyamatok mellett a pszichés jellemzók is befolyásolják az alkohol, illetve placeboalkohol fogyasztása következtében fellépő hatásokat. Ez a típusú kompenzálás kondicionálással erősíthető, generalizálható más helyzetekre, és ki is oltható a jutalom elhagyásával.

A mindennapi placebók múködésének megértése érdekében tehát érdemes vizsgálni, hogy az alkoholfogyasztás hite, illetve maga a tényleges alkoholfogyasztás hogyan hat az emberre, illetve mennyiben képes módosítani ezen a hatáson a társas közeg és a fogyasztáshoz társult információ. Csupán az etanoltól leszünk kótyagosak, vagy más tényezők is szerepet játszanak?

\section{A vizsgálat}

Jelen vizsgálat egyedinek tekinthetó a placebovizsgálatok körében abból a szempontból, hogy nem orvosi és gyógyszerkutatási célból vizsgálja az alkohol és az placeboalkohol hatását egyéni és társas közegben kiegyensúlyozott (balanced) placebo kutatási elrendezésben, külön hangsúlyt fordítva azon változatra is, amelyben a résztvevők alkoholt fogyasztanak, de placebónak vélik azt.

A vizsgálat másik specifikuma, hogy a placebohatást egyéni és csoportos helyzetben is vizsgálja, számolva azzal, hogy a csoportfolyamatok jelentősen befolyásolhatják az eredményeket, annak megfelelően, hogy a hétköznapokban az alkoholfogyasztás nagyrészt társas körülmények között zajlik, így az alkoholhoz kapcsolódó elvárások is ilyen helyzetekhez kapcsolódnak.

Feltételezzük egyrészről, hogy az alkohol indukálta állapot kialakulásáért az etanol csak részben felelős, és hogy az elvárásoknak kiemelt szerepe van. A szocializációval és tapasztalattal elsajátított ittassághoz kapcsolódó elvárások tehát a fogyasztás következtében bekövetkező állapotváltozás jelentôs részét képesek magyarázni. Továbbá feltételezzük, hogy ez a hatás erőteljesebben jelentkezik abban az esetben, ha az alkoholfogyasztás társas környezetben történik, és kevésbé jelentkezik abban az esetben, ha egyedül. 
Az információs hatással kapcsolatban feltételezzük továbbá, hogy az elvárások nemcsak placebo „irányba”, de ellentétes módon is befolyásolják az ittassági állapotot, vagyis azok, akik úgy hiszik, hogy alkoholmentes koktélt kapnak, kevésbé lesznek ittasak, mint azok, akik tudatában vannak annak, hogy etanolt is tartalmaz az italuk. Konkrét hipotéziseink a következők voltak:

1. Egyéni fogyasztás esetében, ha a kísérleti személyek úgy hiszik, hogy alkoholt fogyasztanak, miközben egy részük valójában csupán aromát, az alkoholt és az aromát fogyasztók eredményei nem térnek el egymástól szignifikánsan a szubjektív állapot tekintetében.

2. Az alkoholt és aromát fogyasztó csoport szignifikánsan különbözik egymástól a memória és az egyensúly romlását tekintve: az alkoholt fogyasztók rosszabbul teljesítenek a memória és egyensúly feladatokban az aromát fogyasztókhoz képest.

3. Az egyéni és a csoportos feltételben alkoholt, illetve aromát fogyasztó résztvevők eredményei szignifikánsan eltérnek egymástól a memória, egyensúly és szubjektív állapot tekintetében: a csoportosan résztvevők rosszabbul teljesítenek a memória és egyensúly feladatokban és több „alkoholtünetról" számolnak be az egyénileg résztvevőkhöz képest.

4. Az alkoholt fogyasztó és ennek tudatában lévők (C feltétel: csoportos/alkoholt hisz/ alkoholt kap), illetve az alkoholt fogyasztó, de ezzel kapcsolatban megtévesztett résztvevők ( $D$ feltétel: csoportos /aromát hisz/alkoholt kap) eredményei szignifikánsan eltérnek egymástól a memória, egyensúlyérzék és szubjektív állapot mentén: a megtévesztett, aromát hívő csoport (D feltétel) ,józanabb marad”, jobb teljesítményt mutat a memória és egyensúly feladatokban, illetve kevesebb „alkoholtünetról” számol be, mint az alkoholfogyasztással kapcsolatban helyesen informált résztvevők ( $\mathrm{C}$ feltétel).

\section{Módszer}

\subsection{Kísérleti feltételek és eljárás}

A kutatást az Eötvös Loránd Tudományegyetem (ELTE) Pedagógiai és Pszichológiai Karának Kutatásetikai Bizottsága jóváhagyta (az etikai engedély száma: 2017/114).

Jelen kísérleti elrendezés részben megfelel a balanced placebo design-nak, vagyis a kísérlet során mind a kísérleti személyek által elfogyasztott ital alkoholtartalmát, mind pedig az elvárásaikat változtattuk, azonban a hagyományos balanced placebo design "placebót kap - placebót tud" feltételét nem vizsgáltuk. 
A kutatásra a résztvevőket egy közösségi oldalon (Facebook) meghirdetett felhívással, továbbá a nagyobb budapesti egyetemeken (ELTE, Corvinus Egyetem, Semmelweis Egyetem) elhelyezett 800 szórólap segítségével toboroztuk. Az e-mailben történő jelentkezést követően a résztvevők a fedőtörténetnek megfelelő tájékoztatást kaptak, és egy alkoholfogyasztási szokásokra és demográfiai adatokra vonatkozó kérdőív kitöltésével jelentkezhettek a konkrét vizsgálati időpontokra, amelyekre az ELTE Kazinczy utcai épületének egyik tantermében került sor. A vizsgálat előtt a résztvevők a beleegyező nyilatkozat aláírásával el- és megismerték önkéntes részvételüket, a bizalmas adatok kezelését, a visszalépési lehetőséget és az alkoholfogyasztás esetleges következményeiért a személyüket terhelő felelősséget. Igény esetében a résztvevők utólagos, kollektív visszajelzésben részesültek.

A kutatás során háromféle feltételt alkalmaztunk, fedőtörténettel (1. táblázat), a feltételekbe a résztvevőket random módon soroltuk be. A kísérletben résztvevők minden feltételben $4 \times 4 \mathrm{cl} 37,5 \%$-os rumot, illetve a rumos itallal megegyező színú, szagú és állagú, de alkoholmentes rumaromát kaptak $16 \mathrm{cl}$ kólával keverve. Az első feltételben, vagyis az úgynevezett „egyéni" feltételben résztvevők egyedül vettek részt $(n=37 ; 19$ férfi és 18 nő; átlagéletkor: 23,1 év; SD = 4,13 év). Egy részük (56,8\%-uk) alkoholos, míg a csoport másik része $(43,2 \%)$ csupán aromát tartalmazó koktélt kapott, ugyanakkor azt az információt kapták, hogy mindenki alkoholt fogyaszt.

A második, úgynevezett "csoportos" feltételben, egyszerre 18 fő vett részt 8 férfi és 10 nő; átlagéletkor: 22,5 év; SD = 1,42 év). A kísérleti személyek egymáshoz közel ültek, amely kedvezett a csoporthatásoknak. Ebben a feltételben minden résztvevő valódi rumos koktélt kapott. A csoport azt az információt kapta, hogy nem minden résztvevő kap alkoholt, lesznek, akik csupán aromát tartalmazó, alkoholmentes koktélt kapnak. 15 fő úgy tudta, hogy az „alkoholmentes” feltételbe került és így csupán aromát fogyaszt, míg 3 főt úgy tájékoztattunk, hogy valódi alkoholt fogyaszt, annak érdekében, hogy fent tudjuk tartani a fedőtörténetet.

A harmadik, csoportos feltételben ( $n=81 ; 61$ férfi és 23 nő; átlagéletkor: 22,8 év; $\mathrm{SD}=2,8$ év) a résztvevók egy része $(51,9 \%$-a) valódi, rumos koktélt kapott, míg a másik csoport $(48,1 \%)$ alkoholmentes koktélt. A résztvevők azt az információt kapták, hogy mindegyikük alkoholt fogyaszt. Ez a feltétel nagyrészt megfelel az első feltételnek, azonban ebben az esetben a fogyasztás társas környezetben zajlott, vagyis egyszerre 10-20 fó vett részt a kísérletben. A harmadik feltétel adatait korábban vettük fel (Nagy, 2008; Nagy, Cziboly, \& Bárdos 2007; Nagy, Cziboly, Birtalan, \& Bárdos, 2005), az újabb vizsgálatoknál igyekeztünk a lehető legjobban illeszkedni a korábbi eljáráshoz és módszerekhez. 
1. táblázat. A kísérletben alkalmazott feltételek

\begin{tabular}{|l|l|l|l|c|c|}
\hline & \multicolumn{1}{|c|}{$\begin{array}{c}\text { Információ az elfogyasztott } \\
\text { itallal kapcsolatban }\end{array}$} & $\begin{array}{c}\text { Egyéni/ } \\
\text { Csoportos }\end{array}$ & $\begin{array}{l}\text { Mit fogyasztott } \\
\text { valójában? }\end{array}$ & $n$ & Jel \\
\hline 1. feltétel & úgy tudta, hogy alkoholt fogyaszt & egyéni & alkoholt & 21 & $\mathrm{~A}$ \\
\cline { 4 - 7 } & & & aromát & 16 & $\mathrm{~B}$ \\
\hline \multirow{2}{*}{ 2. feltétel } & úgy tudta, hogy aromát fogyaszt & csoportos & alkoholt & 15 & $\mathrm{D}$ \\
\cline { 3 - 7 } & úgy tudta, hogy alkoholt fogyaszt & csoportos & alkoholt & 3 & $\mathrm{C}$ \\
\hline \multirow{2}{*}{ 3. feltétel } & úgy tudta, hogy alkoholt fogyaszt & csoportos & alkoholt & 42 & $\mathrm{C}$ \\
\cline { 4 - 7 } & & & aromát & 39 & $\mathrm{E}$ \\
\hline
\end{tabular}

Annak érdekében, hogy megvizsgáljuk, hogy a fedőtörténetünk múködött-e, az 1-2 feltétel esetében minden vizsgálat végén megkérdeztük, hogy a résztvevők részegebbnek érzik-e magukat annál, mint amikor megérkeztek a kísérletre. A résztvevők általi válaszokat a 2. táblázat foglalja össze, amelyből látható, hogy az 1 . feltétel mindkét alesetében és a 2 . feltétel "C" alesetében (alkoholt hisz, alkoholt fogyaszt) a válaszok tökéletesen a fedőtörténetnek megfelelóen alakultak, míg a 2. feltétel „ $\mathrm{D}$ ” alesetében a résztvevők 80\%-a annak ellenére, hogy úgy tudta, hogy csak aromát kapott, az alkoholfogyasztás hatására részegebbnek érezte magát távozáskor.

2. táblázat. A különböző feltételekben résztvevők közül hányan vallották magukat részegebbnek az öt mérést követően?

\begin{tabular}{|l|l|c|c|c|c|c|}
\hline \multirow{2}{*}{\multicolumn{2}{|c|}{}} & \multicolumn{3}{|c|}{ Melyik feltételben vett részt? } & \multirow{2}{*}{ Összesen } \\
\cline { 3 - 7 } \multicolumn{2}{|c|}{} & $\boldsymbol{A}$ & $\boldsymbol{B}$ & $\boldsymbol{D}$ & $\boldsymbol{C}$ & \\
\hline $\begin{array}{l}\text { A vizsgálat végén részegebbnek } \\
\text { vallotta-e magát, mint a terembe } \\
\text { lépéskor? }\end{array}$ & igen & 21 & 16 & 12 & 3 & 52 \\
\cline { 2 - 7 } & nem & 0 & 0 & 3 & 0 & 3 \\
\hline Összesen & & 21 & 16 & 15 & 3 & 55 \\
\hline
\end{tabular}

\subsection{Mérőeszközök}

Az alkoholos hatás mérésére a kísérlet során 5 mérési időpontban - az első koktél elfogyasztása előtt, majd minden italt követően, 10 percenként a következő próbákat használtuk: 
A rövidtávú memória teljesítmény mérésére az Általános Pszichológiai Gyakorlatok I. (Dúll, Varga, \& Gősiné Greguss, 1992) 42. számú mellékletének szólistáit alkalmaztuk.

Az egyensúlyérzék felméréséhez az úgynevezett „részegállást” alkalmaztuk. A részegállás esetében az egyik lábat meg kell emelni derékszögig, előrehajolni, és két kézzel hidat kell képezni az orr és a térd között.

A testi-lelki állapot szubjektív megitélésének felmérésére az alkoholos állapotra jellemző tünetlisták alapján összeállított, 17 tulajdonságpárból (gátolt - felszabadult, visszahúzódó - társasági, szomorú - vidám, álmos - éber, tiszta tudatú - tompa tudatú, koncentráló - zavart, paszszív-kezdeményező, szubmisszív - domináns, hallgatag-beszédes, teljesen józan-erósen ittas, nyugodt gyomor - felkavart gyomor, apatikus - érdeklődő, félénk - bátor, jó közérzet - rossz közérzet, racionális - irracionális, megfontolt-impulzív, bizonytalan-magabiztos) álló szemantikus differenciál skálát alkalmaztunk. A testi-lelki állapot skálán az egyes tételekre vizuális analóg skálán történt a válaszadás. A skálaképzés során a $10 \mathrm{~cm}$-es szakaszt egy 100 pontos Likert-skálává alakítottunk át, amelynél minden egység 1 mm-nek felelt meg. Az eredmények kialakításához lemértük, hogy a személy hány mm-nél jelölt, és ezzel az adattal dolgoztunk a továbbiakban.

\subsection{Alkalmazott statisztikai elemzések}

A testi-lelki állapot skálán a 17 változópár kapcsolatát feltáró (exploratív) faktoranalízissel (EFA), maximum likelihood elemzéssel, Varimax rotációval elemeztük az öt mérés mindegyikében, a következő feltételek teljesülése mellett: az input változók együttes eloszlása normális, a KolmogorovSmirnov próba a legtöbb változó esetén nem szignifikáns, a KMO próba adekvációs aránymutatója elfogadható és minden mérés esetében meghaladja a 0,6-ot; a Bartlett-féle szfericitás próba is határozottan szignifikáns $(p<0,001)$ minden esetben; az anti-image mátrix: MSA (Measure of Sampling Adequacy) > 0,5 és a fóátlón kívüli értékek a 0-hoz közelítenek; továbbá a kommunalitások értékei között sincsenek nagyon kicsi értékek $(>0,25)$. A skála belső megbízhatóságának becslésére Cronbach-a mutatót számítottunk.

A hipotézisek tesztelésére kétszempontos vegyes varianciaanalízist (General Linear Model, GLM - Repeated Measures) alkalmaztunk. Az elemzésekhez az SPSS program 14.0 verzióját használtuk. 


\section{Eredmények és diszkusszió}

\subsection{A testi-lelki állapot skála pszichometriai elemzése}

A testi és lelki jóllét szubjektív megítélését mérő skálán végzett feltáró faktoranalízis eredményeképpen mind az öt mérés esetében lényegében ugyanazt a struktúrát kaptuk. Az 5. mérés lejtődiagramját az 1. ábra szemlélteti.

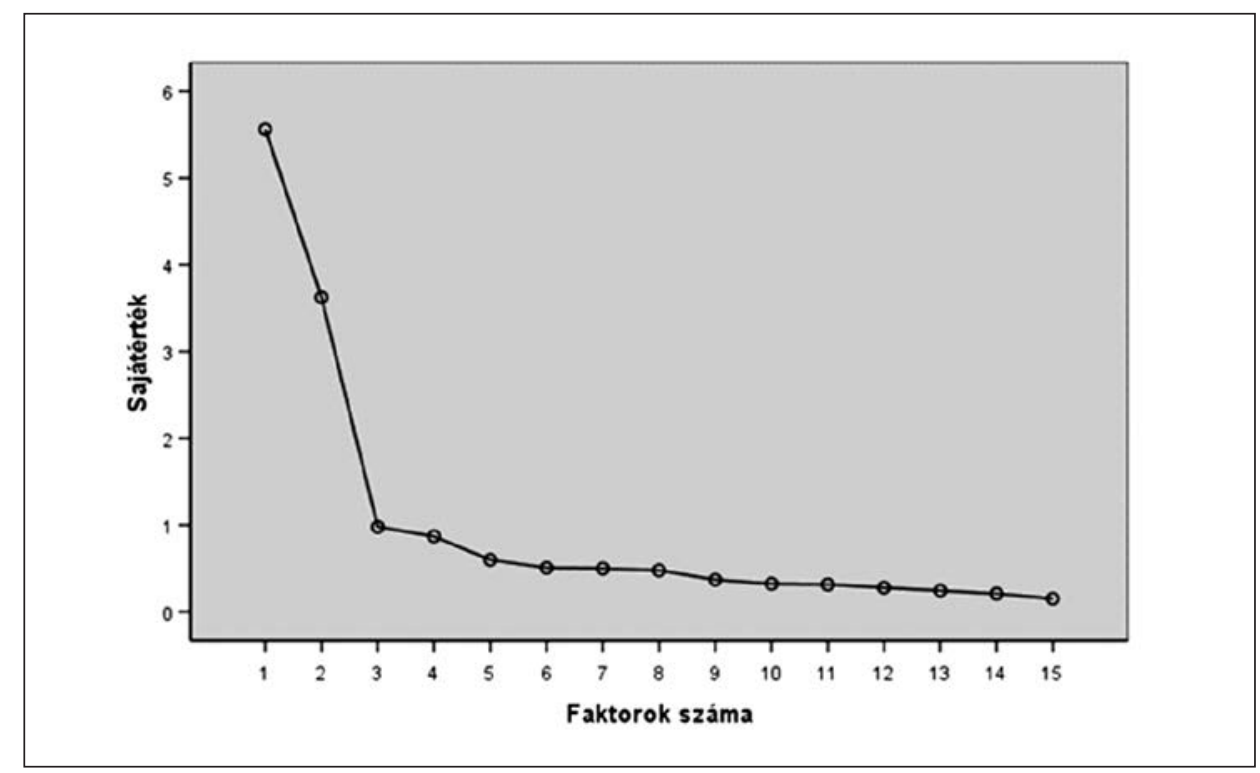

1. ábra. Az ötödik mérés lejtődiagramja

Eredményeink szerint két faktort érdemes kiemelni, amelyek sajátértéke és kumulatív varianciája a 3. táblázat által összefoglalt eredmények szerint alakult a mérések során.

A sajátértékek és megmagyarázott varianciák alapján a két elsődleges faktoron túl további két, úgynevezett másodlagos faktort (3. és 4. faktor) lehet kiemelni, amelyek alkalmazásával a megmagyarázott összes variancia csak csekély mértékben nő, azonban ezek figyelembevételével az összes variancia eléri a $60 \%$-ot, illetve bizonyos méréseknél ezek sajátértéke meghaladja az 1-et. 
3. táblázat. Az exploratív faktoranalízis eredményei az egyes mérési pontokon

\begin{tabular}{|c|c|c|c|}
\hline Mérés & Faktorok száma & Sajátérték & Kumulatív variancia \\
\hline \multirow{2}{*}{ 1. mérés } & 1. faktor & 4,65 & $27,3 \%$ \\
\cline { 2 - 4 } & 2. faktor & 2,94 & $44,6 \%$ \\
\hline \multirow{2}{*}{ 2. mérés } & 1. faktor & 6,02 & $35,4 \%$ \\
\cline { 2 - 4 } & 2. faktor & 3,51 & $56,0 \%$ \\
\hline \multirow{2}{*}{ 3. mérés } & 1. faktor & 6,49 & $38,2 \%$ \\
\cline { 2 - 4 } & 2. faktor & 3,39 & $58,1 \%$ \\
\hline \multirow{2}{*}{ 4. mérés } & 1. faktor & 5,89 & $34,7 \%$ \\
\cline { 2 - 4 } & 2. faktor & 3,96 & $58,0 \%$ \\
\hline \multirow{2}{*}{ 5. mérés } & 1. faktor & 5,90 & $34,7 \%$ \\
\cline { 2 - 4 } & 2. faktor & 3,97 & $58,0 \%$ \\
\hline
\end{tabular}

Az összességében kapott négyfaktoros struktúráról az ötödik mérés alapján az első faktort (sajátérték: 5,90; $\mathrm{R}^{2}=34,7 \%$ ) a rajta töltődő tételek (passzív - kezdeményező, visszahúzódó - társasági, hallgatag - beszédes, szomorú - vidám, gátolt - felszabadult, félénk - bátor, bizonytalan - magabiztos, szubmisszív - domináns, apatikus - érdeklődő) alapján szociális viselkedések faktorként definiáltuk. A másodikat (sajátérték: 3,97; $\mathrm{R}^{2}=58,0 \%$ ) a tiszta tudatú-tompa tudatú, koncentrált-zavart, racionális-irracionális, teljesen józan-erősen ittas, megfontolt-impulzív, nyugodt gyomor-felkavart gyomor változók mentén testi tünetek faktornak neveztük el. A racionális-irracionális és megfontolt-impulzív változók a négyfaktoros struktúra esetén a harmadik faktorhoz (sajátérték: 1,18; $\mathrm{R}^{2}=65,0 \%$ ) tartoznak, amelyet impulzivitás faktornak, a negyedik faktort (sajátérték: 1,04; $\mathrm{R}^{2}=71,12 \%$ ) pedig közérzet faktornak neveztük el, mert egyedül a jó közérzet-rossz közérzet változót tartalmazta.

Mivel a faktorstruktúrában az álmos - éber változók több faktoron is hasonlóan súlyozódtak, a jó közérzet - rossz közérzet változók pedig egyedül alkottak egy „másodlagos faktort”, ezért ezeket kihagytuk a további elemzésből. Az így kapott eredmények egyértelmúen megerősítik a kétfaktoros struktúrát, ahol az első faktor sajátértéke 5,56 $\left(\mathrm{R}^{2}=37,1 \%\right)$, a másodiké pe$\operatorname{dig} 3,62\left(\mathrm{R}^{2}=61,2 \%\right)$. Ez utóbbi elemzés eredményeként kapott faktorsúlyokat a 4. táblázatban mutatjuk be. 
4. táblázat. A rotált faktormátrix az 5. mérés eredményeiből, 15 változóval

\begin{tabular}{|l|c|c|}
\hline \multirow{2}{*}{ Tételek } & \multicolumn{2}{|c|}{ Faktorsúlyok } \\
\cline { 2 - 3 } & $\begin{array}{c}\text { 1. Szociális viselkedések } \\
\text { faktor }\end{array}$ & $\begin{array}{c}\text { 2. Testi tünetek } \\
\text { faktor }\end{array}$ \\
\hline passzív - kezdeményezó & 0,86 & \\
\hline visszahúzódó - társasági & 0,85 & \\
\hline hallgatag - beszédes & 0,82 & \\
\hline szomorú - vidám & 0,82 & \\
\hline gátolt - felszabadult & 0,81 & \\
\hline félénk - bátor & 0,80 & \\
\hline bizonytalan - magabiztos & 0,69 & 0,87 \\
\hline szubmisszív- domináns & 0,66 & 0,81 \\
\hline apatikus - érdeklódő & 0,65 & 0,81 \\
\hline tiszta tudatú - tompa tudatú & & 0,76 \\
\hline koncentrált - zavart & & 0,78 \\
\hline racionális - irracionális & & \\
\hline teljesen józan - erösen ittas & & \\
\hline megfontolt - impulzív & & \\
\hline nyugodt gyomor - felkavart gyomor & & \\
\hline
\end{tabular}

Megjegyzés: Varimax rotáció, a faktorok 3 iteráción belül összeálltak.

A testi-lelki állapot skála belső megbízhatóságának mutatóit a különböző mérések során az 5. táblázat foglalja össze. A Cronbach-a értéke 0,68 és 0,93 értékek között ingadozik. A szociális viselkedések faktoron súlyozódó változók elsó mérésének kivételével, minden más esetben a Cronbach-a értéke megfelelő, 0,7-nél nagyobb. Az első mérés alacsonyabb belső megbízhatóságát az okozhatja, hogy a kísérlet manipuláció előtt az érkező személyek nagyon különböző testi és lelki állapotban érkezhettek a vizsgálatra és ennek megfelelően a válaszaik is nagyon különbözőek. A teszt látszatérvényessége megfelelő, a kritérium validitását azonban a teszt céljának általánossága, és más hasonló konstruktumot mérő battériák hiánya miatt nem vizsgáltuk. 
5. táblázat. A testi-lelki állapot skála belső megbízhatósága (Cronbach-a mutatók)

\begin{tabular}{|l|c|c|c|c|c|}
\hline $\begin{array}{c}\text { Faktor } \\
\text { (tételek száma) }\end{array}$ & 1. mérés & 2. mérés & 3. mérés & 4. mérés & 5. mérés \\
\hline 1. Szociális viselkedések (9) & 0,68 & 0,91 & 0,93 & 0,91 & 0,92 \\
\hline 2. Testi tünetek (6) & 0,71 & 0,83 & 0,84 & 0,87 & 0,86 \\
\hline
\end{tabular}

A két faktoron súlyozódó változók segítségével egy-egy új változót hoztunk létre, amelyeket szociális viselkedések faktornak és testi tünetek faktornak neveztünk el. Az összevont változó úgy jön létre, hogy az adott faktor változói mentén, a faktorsúlyokkal súlyozva összeadjuk a személyek szubjektív skálán, 1-től 100-ig adott pontszámait, majd elosztjuk azokat a faktorsúlyok összegével (a továbbiakban: „átlagok (korrigált mutató)”). Annak érdekében, hogy a csoportok közötti kezdeti különbségekből adódó eltéréseket, „álkülönbségeket” kontroll alatt tartsuk, minden elemzés esetében végrehajtottunk egy úgynevezett „korrigált" elemzést. A korrigált elemzés során a 2-5. mérési eredményekból kivonjuk az első mérés eredményeit, és a továbbiakban ezzel a kivonással korrigált delta mutatóval számolunk.

Az öt csoport a szubjektív skálán adott pontszámok alapján létrehozott két faktor, vagyis a szociális viselkedések és a testi tünetek faktor mentén eltérő mintázatot mutat.

A különböző csoportok mintázatát a szociális viselkedések faktor esetében a 2. ábra foglalja össze. Az eltérő mintázat ellenére az ismételt méréses varianciaanalízis eredménye nem mutat sem szignifikáns idő fóhatást $(F(1)=$ $0,285 ; p=0,594)$, sem interakciós hatást $(F(4)=0,636 ; p=0,638)$ sem pedig eltérést a csoportok között $(F(4)=0,794 ; p=0,531)$, jól látszik azonban, hogy a D és az E feltétel eredményei eltérnek a többitól. Az elóbbi feltételben részt vevők (D: csoportos/aromát hisz/alkoholt kap), vagyis akik csoportosan fogyasztottak alkoholt, miközben úgy hitték, hogy aromát isznak, csökkenő tendenciát mutatnak a szociális viselkedések faktoron a mérések során, egyre kevésbé "sszociálisak”, társaságiak, kezdeményezők, beszédesek, stb., a manipulált információ hatása mutatkozik meg. Ezt magyarázhatjuk egyrészról úgy, hogy a manipulált információ, miszerint nem alkoholt isznak, „elvette a kedvüket”, és emiatt váltak kevésbé szociálissá, illetve másrészről úgy, hogy az információ hatására kompenzálták a viselkedésüket, hiszen „,semmi sem indokolta, hogy szociálisabbá váljanak”. Az utóbbi feltétel (E: csoportos/alkoholt hisz/aromát kap) résztvevői, vagyis akik csoportosan aromát fogyasztva úgy hitték, hogy alkoholt isznak, a többi csoportnál magasabb értéket érnek el, szociálisabbnak vallják magukat és felhangoltabban távoztak a kísérlet helyszínéről a másik négy feltétel résztvevőihez képest, tehát a kompenzáció az ellenkező irányban is megjelent. 
A másik három csoport a 3. mérésig nagyjából hasonló mintázatot mutat, nem tér el jelentősen a mérések során, az utolsó két mérési idópontra azonban a csoportosan alkoholt fogyasztók és ennek tudatában lévők (C feltétel: csoportos/alkoholt hisz/alkoholt kap) emelkedő, miközben az egyénileg szintén alkoholt fogyasztó, és ezzel kapcsolatosan helyes információval rendelkezők (A feltétel: egyéni/alkoholt hisz/alkoholt kap), csökkenő tendenciát mutatnak. Az egyénileg aromát fogyasztók (B feltétel: egyéni/alkoholt hisz/aromát kap) eredményei nem változnak a mérések mentén. Az eredmények kevésbé függenek az elfogyasztott ital alkoholtartalmától, mint attól, hogy egyéni vagy társas feltételben fogyasztották azt el, tehát a hatást vélhetően inkább a különböző társas folyamatok befolyásolták, mint maga az etanol.

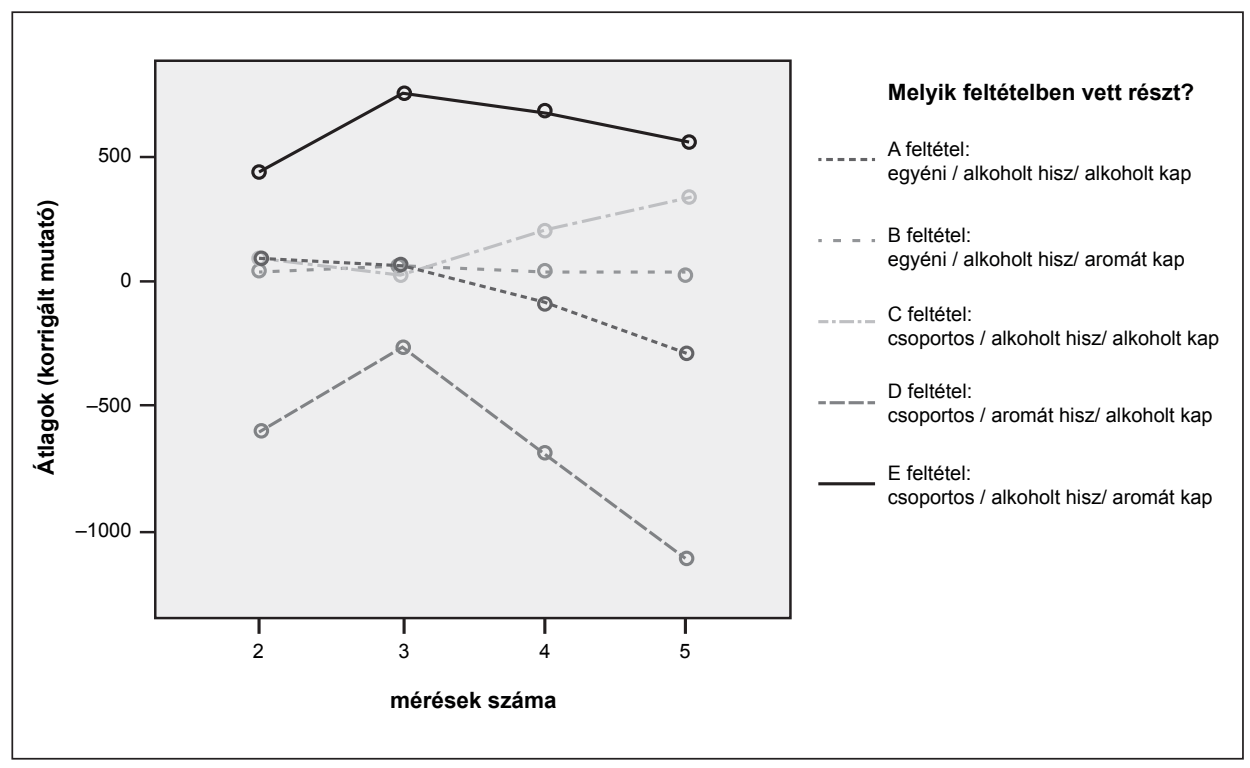

2. ábra. Az öt csoport átlaga a szociális viselkedések faktor mentén az egyes mérési pontokon

A testi tünetek faktor esetében (3. ábra), vagyis a 2. faktor mentén sincsen a csoportok között szignifikáns különbség $(F(4)=0,864 ; p=0,488)$, továbbá az ANOVA nem jelez sem főhatást $(F(3)=0,405 ; p=0,750)$, sem pedig interakciós hatást $(F(12)=0,606 ; p=0,838)$. Az ábrából azonban jól leolvasható azon tendencia, miszerint az alkoholos és az aromás egyéni feltétel (A és $B$ feltétel) résztvevői nagyon hasonló mintázatot mutatnak a testi tünetek tekintetében. Azok, akik csoportosan vettek részt a kísérletben és úgy hitték, hogy alkoholt kaptak, egyre növekvő testi tünetekről (tompa tudat, zavart, erősen ittas, felkavart gyomor, impulzív és irracionális) számolnak be. Érdekes módon közülük a valóban alkoholt fogyasztók (C feltétel: csoportos/ 
alkoholt hisz/alkoholt kap) esetében ez a változás enyhébb, mint az aromát fogyasztóknál (E feltétel: csoportos/alkoholt hisz/aromát kap), akiknél az 1. és a 3. mérést követóen növekedés tapasztalható, amelyet kompenzációnak, placebohatásnak tekinthetünk. A csoporthatás tehát erősebb bejóslója az eredményeknek, mint maga az etanol. A csoportosan résztvevők, függetlenül attól, hogy mit fogyasztanak valójában, egyre több részegséggel kapcsolatos tünetről számolnak be, miközben az egyénileg részt vevők nem változnak jelentősen ebból a szempontból a mérések során. A kísérlet során elfogyasztott mennyiség, illetve a koktélok között eltelt rövid idő nem indokolja a részegség testi tüneteinek megjelenését, kevés a teljes alkoholhatás kialakulásához, a csupán aromát fogyasztók esetén pedig ezen tünetek indokolatlanok, mégis a testi tünetekkel kapcsolatos erós sztereotípiáink hatására akkor is „kreálnak” maguknak ilyen tüneteket, amikor azt hiszik, hogy alkoholt ittak. A D feltétel (csoportos, aromát hisz, de alkoholt kap) résztvevői pedig az elvárásaiknak megfelelően egyre kevesebb tünetet produkálnak, az önjellemzős skálán adott válaszaik alapján egyre alacsonyabb értéket érnek el a testi tünetek faktoron, az etanollal szemben győz az a tudat, miszerint „"csak placebót kapok, nem érezhetem magam berúgva”. További érdekesség, hogy az elvárások hatását befolyásolja a közeg: egyénileg a testi tünetekkel kapcsolatosan csak mérsékelten, míg csoportosan viszont markánsabban jelenik meg az elvárások hatása. Egyénileg az aromát fogyasztók a valódi alkoholt ivókhoz hasonló tünetekről számolnak be, míg csoportosan a tünetek felerősödnek.

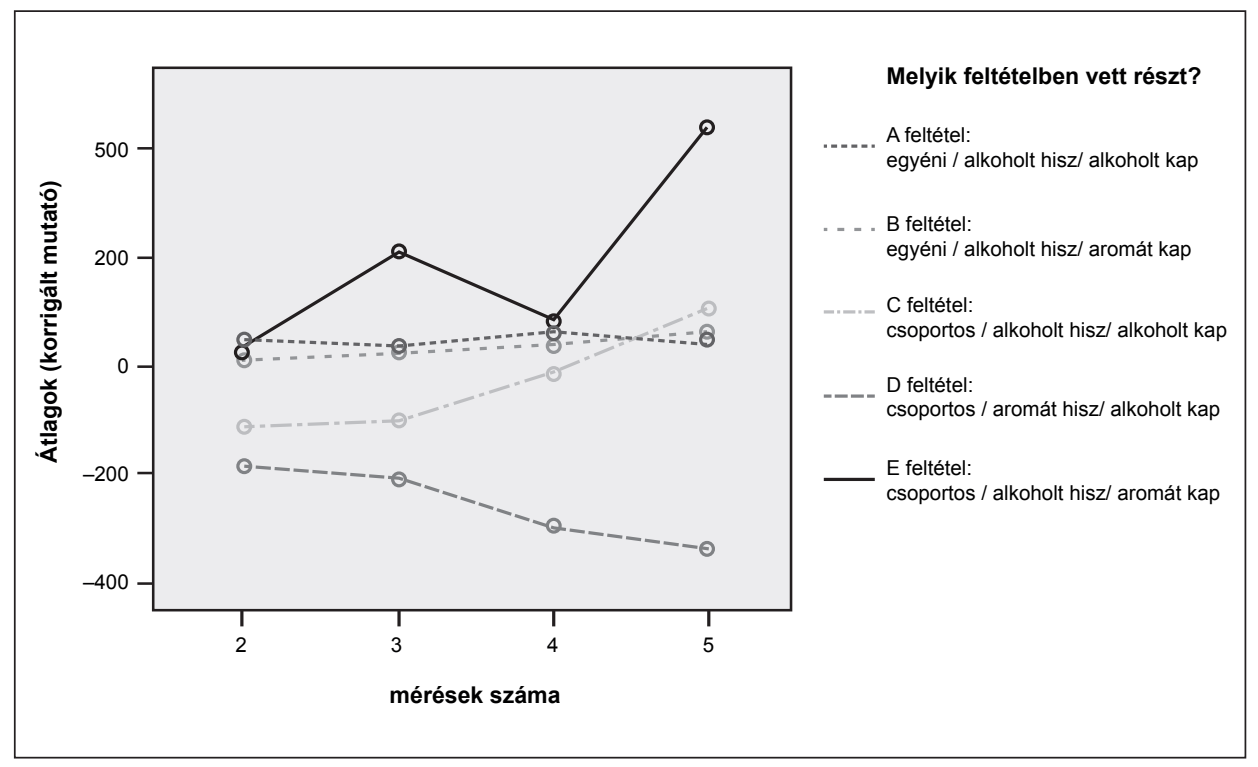

3. ábra. Az öt csoport átlaga a testi tünetek faktor mentén az egyes mérési pontokon 


\subsection{Hipotézisellenőrzés}

4.2.1. Egyéni feltételben, amennyiben a kísérleti személyek úgy hiszik, hogy alkoholt fogyasztanak, miközben egy részük valójában csupán aromát kap, az alkoholt és az aromát fogyasztók eredményei nem térnek el egymástól szignifikánsan a szubjektí állapot tekintetében.

A hipotézist kétszempontos vegyes, 5x2-es varianciaanalízis (VA) segítségével teszteltük, ahol a mérési időpontok adták a csoporton belüli (within subject), míg a feltételek (alkoholt és aromát fogyasztók az első feltételben, vagyis az A és B feltétel) a csoportok közötti (between subject) varianciát. A szfericitás próba sérülése miatt a robosztus alternatívák eredményeit vettük figyelembe. A VA sem a szociális viselkedések, sem pedig a testi tünetek faktor esetén nem jelez szignifikanciát, sem fó-, sem pedig interakciós hatásként (6. táblázat).

6. táblázat. A varianciaanalízis eredményei: Az A és B feltételben résztvevők eredményei a szubjektív skálára adott válaszok mentén

\begin{tabular}{|c|l|c|c|c|c|c|}
\hline \multicolumn{1}{|c|}{ Változók } & \multicolumn{1}{|c|}{ Hatás } & df & $\mathbf{F}$ & $\mathbf{p}$ & $\begin{array}{c}\text { Parciális } \\
\text { éta négyzet }\end{array}$ & $\begin{array}{c}\text { Statisztikai } \\
\text { eró }\end{array}$ \\
\hline $\begin{array}{l}\text { Szociális } \\
\text { viselkedések }\end{array}$ & idő & 1,293 & 1,054 & 0,330 & 0,032 & 0,187 \\
\cline { 2 - 7 } & $\begin{array}{l}\text { feltétel } \\
\text { (alkohol/aroma) }\end{array}$ & 1 & 0,234 & 0,632 & 0,007 & 0,076 \\
\cline { 2 - 7 } & idő $\times$ feltétel & 1,293 & 0,848 & 0,390 & 0,026 & 0,159 \\
\hline \multirow{2}{*}{ Testi tünetek } & idő & 1,236 & 1,066 & 0,324 & 0,032 & 0,185 \\
\cline { 2 - 7 } & $\begin{array}{l}\text { feltétel } \\
\text { (alkohol/aroma) }\end{array}$ & 1 & 0,191 & 0,665 & 0,006 & 0,071 \\
\cline { 2 - 7 } & idő $\times$ feltétel & 1,236 & 0,935 & 0,359 & 0,028 & 0,168 \\
\hline
\end{tabular}

A csoportok tehát nem különböznek egymástól szignifikánsan 0,05-ös valószínúségi értéket választva kritériumszintnek. Tehát az első kísérleti feltételben, ahol a résztvevők egyénileg vettek részt és úgy tudták, hogy alkoholt isznak, míg valójában csak egy részük ivott valódi alkoholt, a többiek aromát fogyasztottak, az alkoholtartalomtól függetlenül mindkét csoport hasonló szubjektív tünetekról számolt be a hasonló elvárásoknak köszönhetően. A hipotézist tehát igazoltuk. 
4.2.2. Az alkoholt és aromát fogyasztó - egyéni és társas feltételben résztvevő - csoportok szignifikánsan különböznek egymástól a memória és az egyensúly romlását tekintve: az alkoholt fogyasztók rosszabbul teljesítenek a memória és egyensúly feladatokban az aromát fogyasztókhoz képest.

A hipotézis tesztelésére kétszempontos vegyes, 5x2-es varianciaanalízist használtunk, az öt mérési időpont során a memóriafeladatban nyújtott teljesítmény átlagai adták a csoporton belüli (within subject), míg az elfogyasztott ital (alkohol, illetve aroma) a csoportok közötti (between subject) varianciát. A szfericitás próba nem szignifikáns, az ivás főhatás nem szignifikáns, azonban az időpont főhatása és az idő $\times$ ital interakciója szignifikánsnak bizonyult (7. táblázat), az alkoholt fogyasztók rosszabbul teljesítenek a szavak felidézésekor.

7. táblázat. Kevert mintás ANOVA: Az alkoholt és aromát fogyasztók eredményei a memória romlását tekintve az 5 mérés során

\begin{tabular}{|l|c|c|c|c|c|}
\hline \multicolumn{1}{|c|}{ Hatás } & df & F & p & $\begin{array}{c}\text { Parciális éta } \\
\text { négyzet }\end{array}$ & $\begin{array}{c}\text { Statisztikai } \\
\text { eró }\end{array}$ \\
\hline idő & 3 & 7,994 & $<0,001$ & 0,057 & 0,991 \\
\hline ital (alkohol/aroma) & 1 & 2,057 & 0,154 & 0,015 & 0,296 \\
\hline idő $\times$ ital & 3 & 3,089 & 0,027 & 0,023 & 0,721 \\
\hline
\end{tabular}

A 4. ábra alapján jellemző mintázat mindkét csoport esetében, hogy a második mérésnél jelentősen megnő a visszaidézett szavak száma az elsőhöz képest, ami valószínúsíthetóen a „,beletanulás” eredménye. Ezt követően a 4. mérésig romlás figyelhető meg mindkét csoportban. A 4. és 5. mérés között az alkoholt fogyasztó csoportnál stagnálás, míg az aromát fogyasztó csoportnál hirtelen javulás figyelhető meg, ami elképzelhető, hogy a megtévesztés lelepleződését jelöli, vagyis azt, hogy a 4. italra a résztvevők rájöttek, hogy nem alkoholt fogyasztanak. Amennyiben az 5. mérés eredményeit nem számoljuk, úgy a szignifikáns különbség eltúnik a két csoport között, így elképzelhető hogy a hipotézis egy artefaktum következtében nyert megerósítést. 


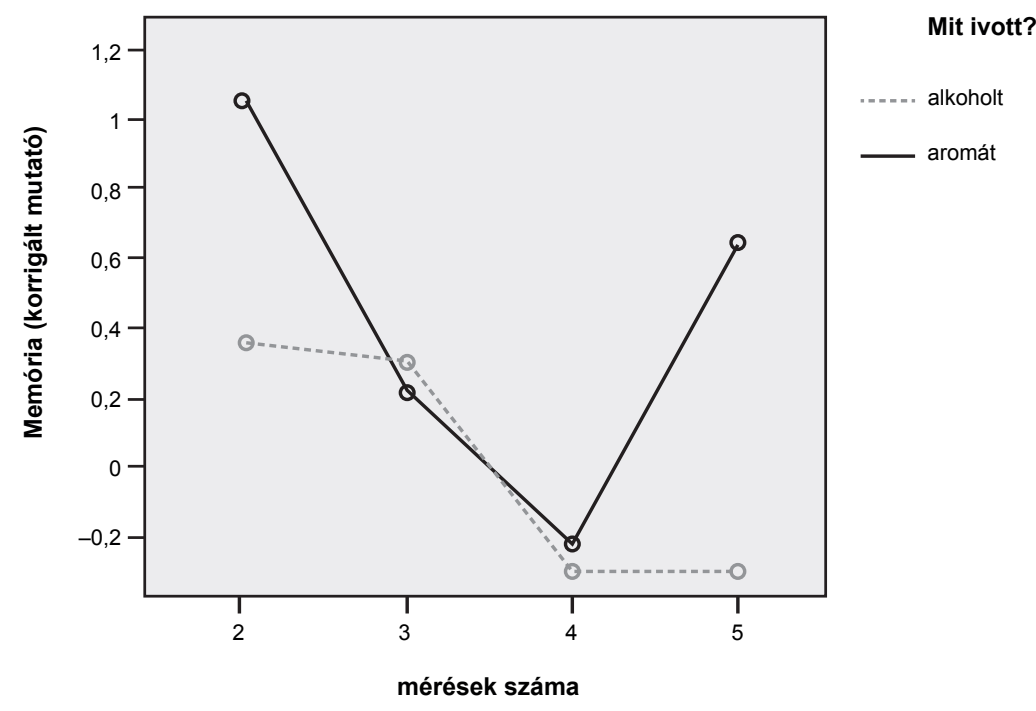

4. ábra. Az alkoholt és aromát fogyasztó csoport eredményei a memória romlását tekintve

Az egyensúlyromlást mérő kétszempontos vegyes, 5×2-es varianciaanalízis eredményeit a 8. táblázat foglalja össze. Az összetartozó minták szóráshomogenitásának sérülése (a Mauchly-féle szfericitás-teszt szignifikáns) miatt a robosztus alternatívák (Greenhouse-Geisser) eredményeit vettük figyelembe, amely nem jelez sem főhatásként, sem pedig interakciós hatásként szignifikanciát, az alkoholt és az aromát ivók csoportja nem különbözik egymástól szignifikánsan az egyensúly romlását tekintve, a hipotézisünk tehát nem nyert megerősítést.

8. táblázat. Kevert mintás ANOVA: Az alkoholt és aromát fogyasztók eredményei az egyensúly romlását tekintve az 5 mérés során

\begin{tabular}{|l|c|c|c|c|c|}
\hline \multicolumn{1}{|c|}{ Hatás } & df & F & p & $\begin{array}{c}\text { Parciális } \\
\text { éta négyzet }\end{array}$ & $\begin{array}{c}\text { Statisztikai } \\
\text { eró }\end{array}$ \\
\hline idő & 2,320 & 2,618 & 0,066 & 0,019 & 0,561 \\
\hline ital (alkohol/aroma) & 1 & 0,181 & 0,671 & 0,001 & 0,071 \\
\hline idő $\times$ ital & 2,320 & 0,595 & 0,576 & 0,004 & 0,157 \\
\hline
\end{tabular}


4.2.3. Az egyéni és a csoportos feltételben alkoholt, illetve aromát fogyasztó résztvevook eredményei szignifikánsan eltérnek egymástól a memória, egyensúly és szubjektív állapot tekintetében: a csoportosan résztvevoók rosszabbul teljesítenek a memória és egyensúly feladatokban és több "alkohol tünetről” számolnak be az egyénileg résztvevőkhöz képest.

Az ezúttal is alkalmazott kétszempontos vegyes VA eredményei (9. táblázat) szerint a memória (5. ábra), és az egyensúly (6. ábra) romlása mentén nincs szignifikáns különbség az alkoholt fogyasztó egyéni és az alkoholt fogyasztó, de csoportosan résztvevők között, a memóriánál azonban az idő főhatása és a feltétel $\times$ idő interakciója szignifikáns, tehát a mérések során mindkét csoportban szignifikánsan romlott a memóriafeladatban nyújtott teljesítmény, az egyéni feltételben résztvevők teljesítménye pedig szignifikánsan nagyobb mértékben romlott a mérések során a csoportos feltételben résztvevőkhöz képest. A szociális viselkedések és a testi tünetek faktor esetében nem találtunk szignifikáns különbséget a két csoport között.

9. táblázat. Kevert mintás ANOVA: Az alkoholt fogyasztó egyéni és csoportos feltételben résztvevők eredményei

\begin{tabular}{|c|c|c|c|c|c|c|}
\hline Változók & Hatás & df & F & $\mathrm{p}$ & $\begin{array}{l}\text { Parciális } \\
\text { éta négyzet }\end{array}$ & $\begin{array}{c}\begin{array}{c}\text { Statisztikai } \\
\text { eró }\end{array} \\
\text { क }\end{array}$ \\
\hline \multirow[t]{3}{*}{ Memória } & idő & 3 & 8,469 & $<0,001$ & 0,097 & 0,993 \\
\hline & $\begin{array}{l}\text { feltétel (egyéni } \\
\text { /csoportos) }\end{array}$ & 1 & 2,916 & 0,092 & 0,036 & 0,393 \\
\hline & idő $\times$ feltétel & 3 & 5,160 & 0,002 & 0,061 & 0,921 \\
\hline \multirow[t]{3}{*}{ Egyensúly } & idő & 2,155 & 2,157 & 0,115 & 0,027 & 0,545 \\
\hline & $\begin{array}{l}\text { feltétel (egyéni) } \\
\text { csoportos) }\end{array}$ & 1 & 3,011 & 0,087 & 0,037 & 0,403 \\
\hline & idő $\times$ feltétel & 2,155 & 0,195 & 0,838 & 0,002 & 0,086 \\
\hline \multirow{3}{*}{$\begin{array}{l}\text { Szociális } \\
\text { viselkedések }\end{array}$} & $i d o$ & 1,059 & 0,689 & 0,417 & 0,010 & 0,132 \\
\hline & $\begin{array}{l}\text { feltétel (egyéni) } \\
\text { csoportos) }\end{array}$ & 1 & 0,188 & 0,666 & 0,003 & 0,071 \\
\hline & idő $\times$ feltétel & 1,059 & 0,056 & 0,828 & 0,001 & 0,056 \\
\hline \multirow[t]{3}{*}{ Testi tünetek } & $i d o$ & 1,051 & 0,056 & 0,825 & 0,001 & 0,056 \\
\hline & $\begin{array}{l}\text { feltétel (egyéni) } \\
\text { csoportos) }\end{array}$ & 1 & 0,579 & 0,449 & 0,008 & 0,117 \\
\hline & idő $\times$ feltétel & 1,059 & 0,097 & 0,769 & 0,001 & 0,061 \\
\hline
\end{tabular}




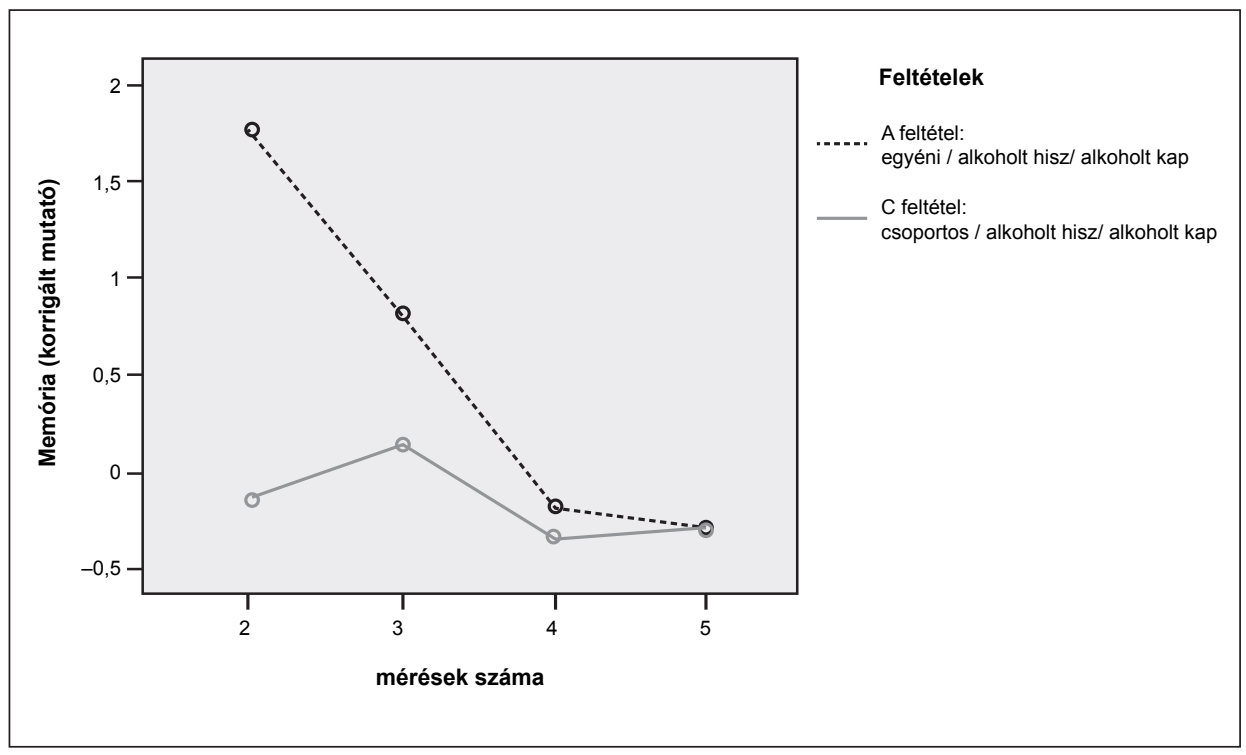

5. ábra. Az alkoholt fogyasztó egyéni és csoportos feltételben résztvevők eredményeinek ábrázolása a memória romlása mentén

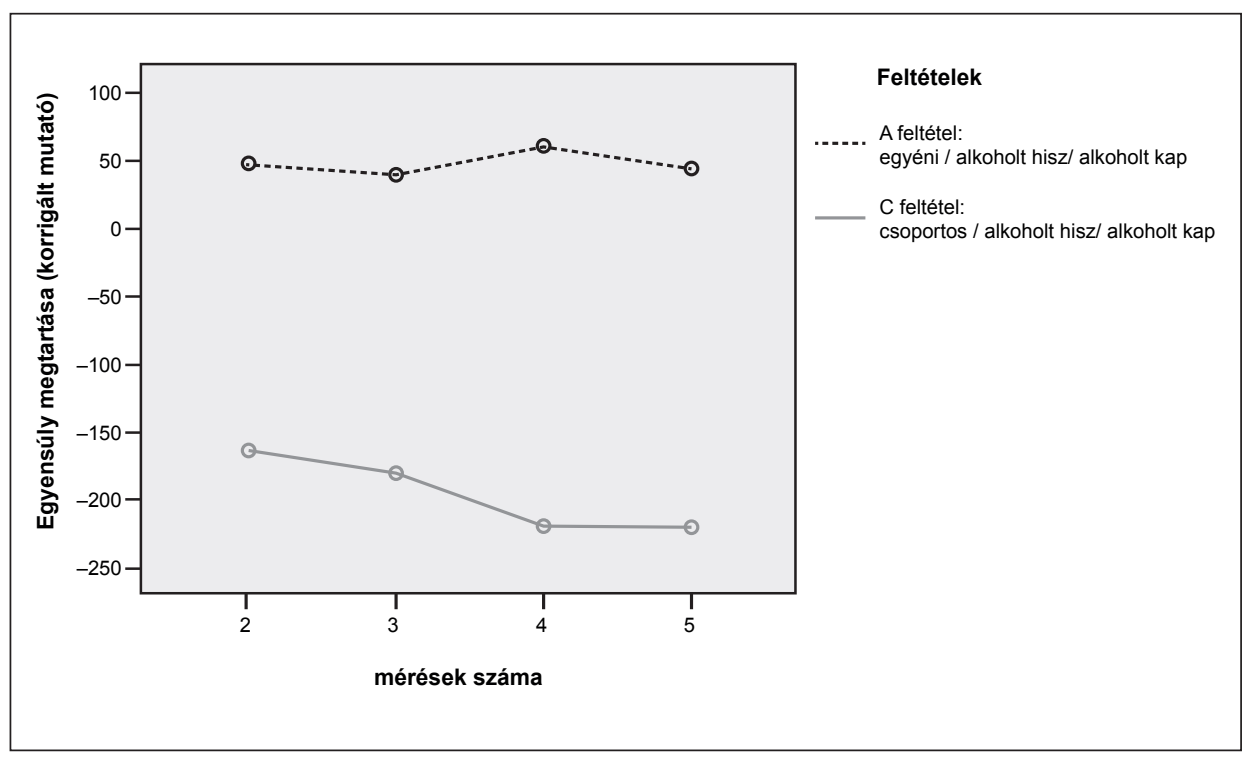

6. ábra. Az alkoholt fogyasztó egyéni és csoportos feltételben résztvevők eredményeinek ábrázolása az egyensúly romlása mentén 
Az aromát fogyasztók esetében a kétszempontos vegyes VA eredményei (10. táblázat) alapján az egyensúly esetében (8. ábra) szignifikáns főhatása van a feltételnek, vagyis annak, hogy egyéni, avagy csoportos feltételben vettek részt az aromát fogyasztók. A memória esetében (7. ábra) idő főhatás és interakciós hatás mutatkozik a feltétel és az eltelt idő mentén, míg a szubjektív skálára adott pontszámok mentén a két csoport nem különbözik szignifikánsan.

10. táblázat. Kevert mintás ANOVA: Az aromát fogyasztó egyéni és csoportos feltételben résztvevők eredményei

\begin{tabular}{|c|c|c|c|c|c|c|}
\hline Változók & Hatás & df & $\mathbf{F}$ & p & $\begin{array}{c}\text { Parciális éta } \\
\text { négyzet }\end{array}$ & $\begin{array}{c}\text { Statisztikai } \\
\text { erő }\end{array}$ \\
\hline \multirow[t]{3}{*}{ Memória } & idő & 3 & 3,594 & 0,015 & 0,065 & 0,784 \\
\hline & $\begin{array}{l}\text { feltétel (egyéni/ } \\
\text { csoportos) }\end{array}$ & 1 & 1,508 & 0,225 & 0,028 & 0,226 \\
\hline & idő $\times$ feltétel & 3 & 2,779 & 0,043 & 0,051 & 0,662 \\
\hline \multirow[t]{3}{*}{ Egyensúly } & idő & 2,399 & 4,093 & 0,013 & 0,072 & 0,773 \\
\hline & $\begin{array}{l}\text { feltétel (egyéni) } \\
\text { csoportos) }\end{array}$ & 1 & 5,066 & 0,029 & 0,087 & 0,599 \\
\hline & idő $\times$ feltétel & 2,399 & 5,447 & 0,003 & 0,093 & 0,886 \\
\hline \multirow{3}{*}{$\begin{array}{l}\text { Szociális } \\
\text { viselkedések }\end{array}$} & idő & 1,225 & 0,454 & 0,542 & 0,009 & 0,107 \\
\hline & $\begin{array}{l}\text { feltétel (egyéni) } \\
\text { csoportos) }\end{array}$ & 1 & 0,422 & 0,519 & 0,008 & 0,098 \\
\hline & idő $\times$ feltétel & 1,225 & 0,409 & 0,566 & 0,008 & 0,101 \\
\hline \multirow[t]{3}{*}{ Testi tünetek } & idő & 1,004 & 0,416 & 0,523 & 0,008 & 0,097 \\
\hline & $\begin{array}{l}\text { feltétel (egyéni) } \\
\text { csoportos) }\end{array}$ & 1 & 0,361 & 0,550 & 0,007 & 0,091 \\
\hline & idő $\times$ feltétel & 1,004 & 0,282 & 0,599 & 0,005 & 0,082 \\
\hline
\end{tabular}




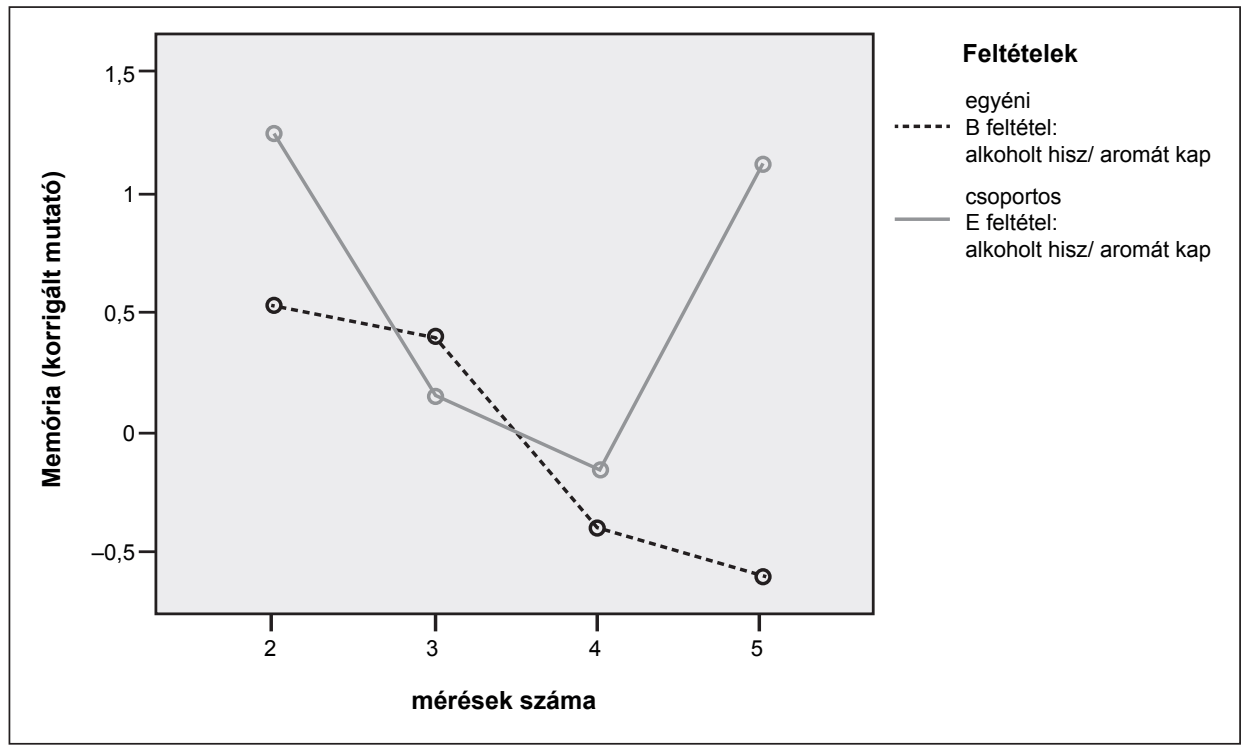

7. ábra. Az aromát fogyasztó egyéni és csoportos feltételben résztvevők eredményeinek ábrázolása a memória romlása mentén

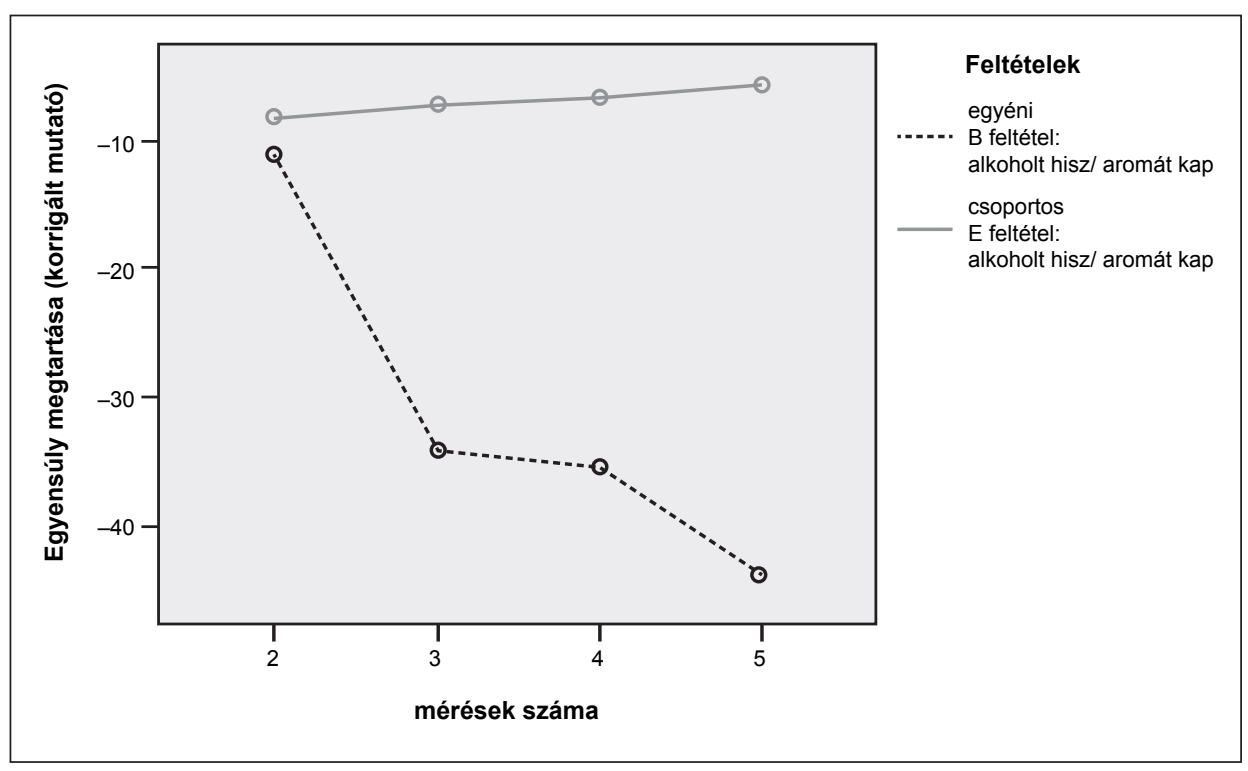

8. ábra. Az aromát fogyasztó egyéni és csoportos feltételben résztvevők eredményeinek ábrázolása az egyensúly romlása mentén 
Az egyensúlymérés esetében a kísérlet során megfigyelhető volt egy bizonyos "dominó hatás”, vagyis ahogy a csoport egyik tagja lerakta a lábát, a többiek szinte azonnal követték és egymás után „dőltek el”, amely hatás markánsan jelent meg az aromát fogyasztóknál (8. ábra) és kevésbé az alkoholt fogyasztók esetében (6. ábra). Tehát a csoporthatás itt a részegség sztereotípia felerősödését jelentette, az egyensúly romlása pedig nem az alkohol hatásának, hanem inkább a csoporthatásoknak, az elvárásoknak és a fáradásnak volt a következménye.

A valódi alkoholt fogyasztóknál a memóriával kapcsolatosan a csoporthatás éppen ellenkező változást váltott ki, javulást eredményezett az egyéni résztvevőkkel összehasonlítva. Az egyénileg résztvevők teljesítménye erőteljesen csökken, míg a csoportos résztvevők nagyjából azonos teljesítményt nyújtanak a mérések során, csupán enyhe romlás figyelhető meg az esetükben. Mivel az alkohol ilyen mennyiségnél, illetve ilyen rövid idő elteltével még nem befolyásolja az emlékezőképességet, így elképzelhető, hogy az egyéni esetben a sztereotípiák aktiválódását, míg a csoportos feltételben pedig egyfajta társas korrekciót mértünk inkább, mint a memóriaromlást. Ez utóbbi esetében arra gondolunk, hogy a résztvevők egymást figyelték és a józannak túnő társak mellett ők is jól teljesítettek, míg egyéni helyzetben a fókusz inkább befelé fordult, a kísérleti személyek a saját testükre figyeltek.

Az aromát fogyasztóknál a memória esetében (7. ábra) idő fóhatás és interakciós hatás mutatkozik a feltétel és az eltelt idő mentén, tehát a két csoport szignifikánsan különbözik egymástól a memória romlását tekintve az öt mérés mentén, a csoportban fogyasztók szignifikánsan több szót tudnak visszaidézni. A második mérés kiugró teljesítménye itt is megfigyelhető mindkét csoportnál, azonban ezt követően az egyéni résztvevők memóriateljesítménye folyamatosan romlik, míg a csoportos résztvevők teljesítménye nem mutat jelentős eltérést a mérések mentén. A hipotézis igazolása megerősíti a korábbi eredményeket, miszerint az emlékezeti hanyatlás nem az elfogyasztott alkohol mennyiségének, hanem sokkal inkább az elvárásoknak köszönhetően jelenik meg. Amennyiben az emberek azt hiszik, hogy alkoholt ittak, akkor rosszabbul teljesítenek. Ez a hatás tisztán jelenik meg egyéni helyzetben, míg csoportos esetben esetleges más hatások, mint például a versengés (jobb felidézés az egyéni helyzethez képest) vagy nagy létszám miatti figyelem terelódése (szabálytalan mintázat az öt mérés mentén), árnyalják az eredményeket.

A szubjektív állapot, vagyis az önjellemzős szociális viselkedések és a testi tünetek mentén nincs különbség a csoportok között, hipotézisünk tehát nem nyert alátámasztást. 
4.2.4. Az alkoholt fogyasztó és ennek tudatában lévők (C feltétel: csoportos/alkoholt hisz/alkoholt kap), illetve az alkoholt fogyasztó, de ezzel kapcsolatban megtévesztett résztvevők (D feltétel: csoportos/aromát hisz/alkoholt kap) eredményei szignifikánsan eltérnek egymástól a memória, egyensúlyérzék és szubjektív állapot mentén: a megtévesztett, aromát hívő csoport (D feltétel) "józanabb marad", jobb teljesitményt mutat a memória és egyensúly feladatokban, illetve kevesebb ",alkohol tünetről" számol be, mint az alkoholfogyasztással kapcsolatban helyesen informált résztvevők (C feltétel).

A hipotézist a csoportos és az egyéni feltételek bevonásával vizsgáltuk. A kétszempontos vegyes VA ezen hipotézis esetében egyik mérésnél sem volt szignifikáns (11. táblázat), így a hipotézisünk nem nyert megerősítést, tehát nincs szignifikáns különbség az alkoholt fogyasztó és ennek tudatában lévő, illetve a szintén alkoholt fogyasztó, de ezzel kapcsolatban megtévesztett személyek memóriája, egyensúlyérzéke és szubjektív állapota között.

11. táblázat. Az ismétléses ANOVA: Az alkoholt fogyasztó megtévesztett és helyesen informált feltételben résztvevők eredményei

\begin{tabular}{|c|c|c|c|c|c|c|}
\hline Változók & Hatás & df & $F$ & $p$ & $\begin{array}{c}\text { Parciális éta } \\
\text { négyzet }\end{array}$ & $\begin{array}{c}\text { Statisztikai } \\
\text { eró }\end{array}$ \\
\hline \multirow[t]{3}{*}{ Memória } & idő & 3 & 0,873 & 0,456 & 0,011 & 0,239 \\
\hline & $\begin{array}{l}\text { feltétel (alkoholt } \\
\text { hisz/aromát hisz) }\end{array}$ & 1 & 0,331 & 0,566 & 0,004 & 0,088 \\
\hline & idő $\times$ feltétel & 3 & 2,555 & 0,056 & 0,031 & 0,625 \\
\hline \multirow[t]{3}{*}{ Egyensúly } & idő & 2,183 & 2,122 & 0,118 & 0,026 & 0,451 \\
\hline & $\begin{array}{l}\text { feltétel (alkoholt } \\
\text { hisz/aromát hisz) }\end{array}$ & 1 & 0,010 & 0,920 & $<0,001$ & 0,051 \\
\hline & idő $\times$ feltétel & 2,183 & 2,038 & 0,129 & 0,025 & 0,436 \\
\hline \multirow{3}{*}{$\begin{array}{l}\text { Szociális } \\
\text { viselkedések }\end{array}$} & idő & 1,060 & 0,085 & 0,787 & 0,001 & 0,060 \\
\hline & $\begin{array}{l}\text { feltétel (alkoholt } \\
\text { hisz/aromát hisz) }\end{array}$ & 1 & 0,400 & 0,529 & 0,006 & 0,096 \\
\hline & idő $\times$ feltétel & 1,060 & 0,711 & 0,410 & 0,010 & 0,135 \\
\hline \multirow[t]{3}{*}{ Testi tünetek } & $i d o$ & 1,052 & 0,220 & 0,653 & 0,003 & 0,075 \\
\hline & $\begin{array}{l}\text { feltétel (alkoholt } \\
\text { hisz/aromát hisz) }\end{array}$ & 1 & 0,123 & 0,727 & 0,002 & 0,064 \\
\hline & idő $\times$ feltétel & 1,052 & 1,575 & 0,214 & 0,022 & 0,241 \\
\hline
\end{tabular}


A szignifikancia hiányának ellenére azonban az ábrák jól mutatják a két csoport teljesítményének változását a mérések során. A memória (9. ábra) esetében azok, akik aromát hisznek, egyre jobban teljesítenek, miközben a helyesen informált csoport teljesítménye folyamatosan romlik. Ezt értelmezhetjük úgy, hogy ismét az elvárások győztek, vagyis „ha nem kaptam alkoholt, akkor miért is teljesítenék rosszabbul?"

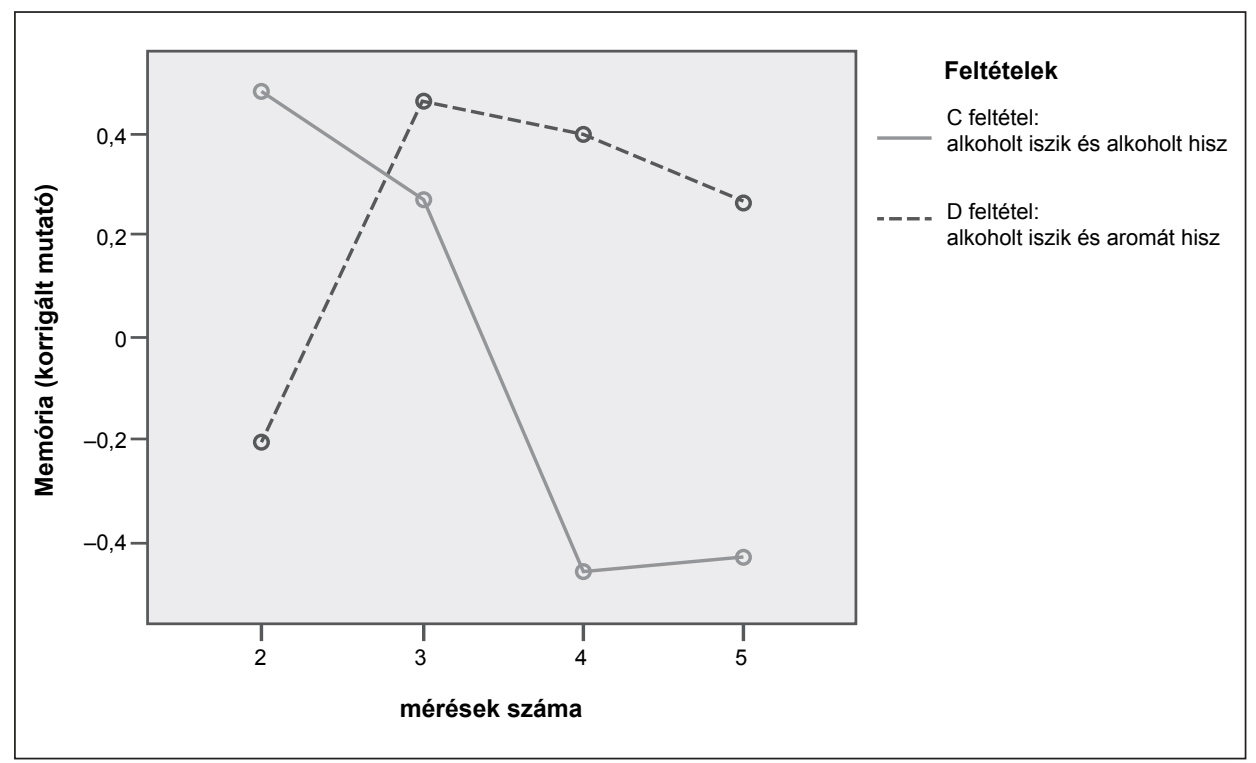

9. ábra. Az alkoholt ivó megtévesztett és helyesen informált résztvevók eredményeinek ábrázolása a memória mentén

Az egyensúly (10. ábra) esetében az alkoholt ivó - alkoholt tudó csoportnál folyamatos romlás, míg az alkoholt ivó-aromát tudó csoportnál egy véletlenszerú mintázat jelenik meg, hol jobban, hol rosszabbul teljesítenek, eredményeik az 5. mérésre haladják meg a helyesen informált csoportét.

A szubjektív állapot mentén a szociális faktor esetén az aromát hívők egyre szociálisabbak, míg az alkoholt tudók egyre kevésbé (11. ábra), a testi tünetek esetében ugyanezen tendencia megjelenése pedig markánsabb (12. ábra). Ezen eredmény, annak ellenére, hogy nem szignifikáns, ellentétes a hipotézisünkkel, hiszen az eredmények alapján azok, akik azt hitték, hogy aromát ittak, „részegebbnek” érezték magukat. Felmerülhet, hogy a megtévesztés nem volt sikeres, és a résztvevők rájöttek, hogy alkoholt isznak, és mintegy „kompenzálásképpen”, felnagyították az alkohol hatását. Ezt a feltételezést megerősíti, hogy a 15 megtévesztett főből összesen 3 állította, hogy nem részegebb annál, mint mikor megérkezett a kísérletre, a maradék 
12 részegebbnek vallotta magát az öt mérést követően. Elképzelhető tehát, hogy fordítva az alkoholt nem lehet teljesen maszkolni, és aromának beállítani, a manipulációnak ugyan lehet hatása, de a megtévesztésre a résztvevők rájöhettek.

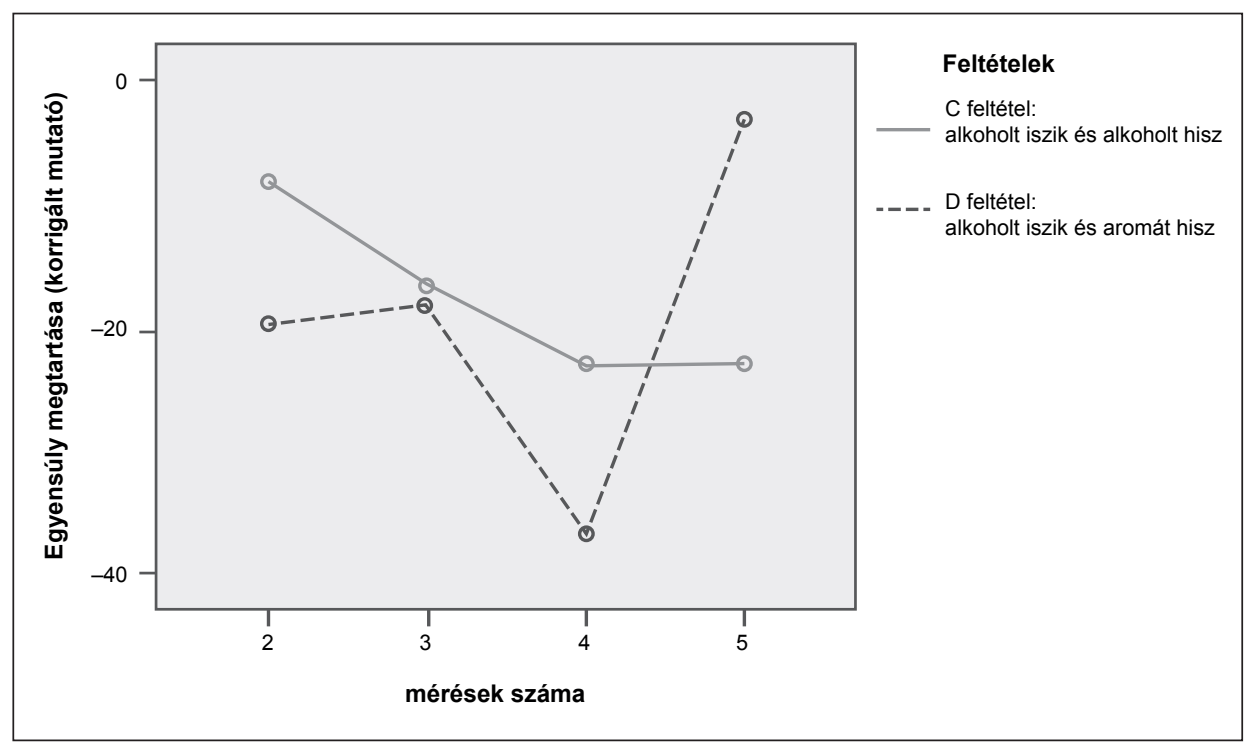

10. ábra. Az alkoholt ivó megtévesztett és helyesen informált résztvevők eredményeinek ábrázolása az egyensúly mentén

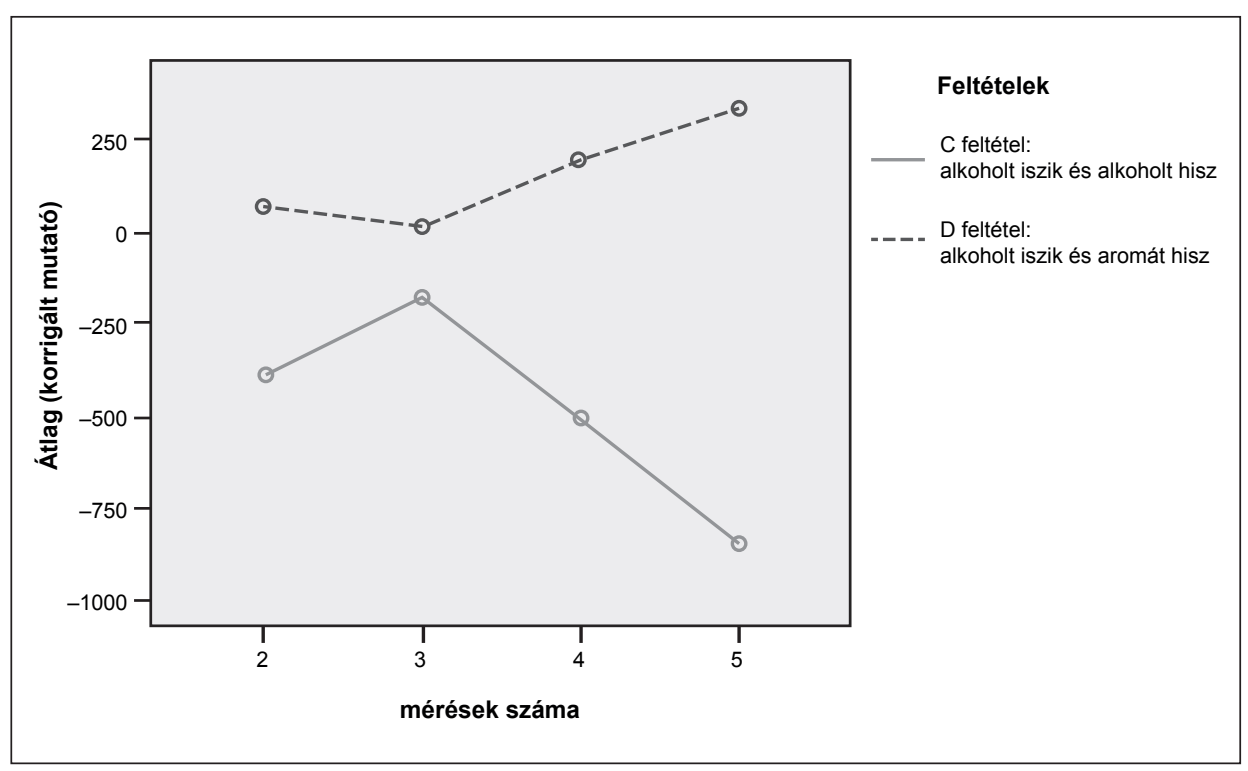

11. ábra. Az alkoholt ivó megtévesztett és helyesen informált résztvevők eredményeinek ábrázolása a szociális viselkedések faktor mentén 


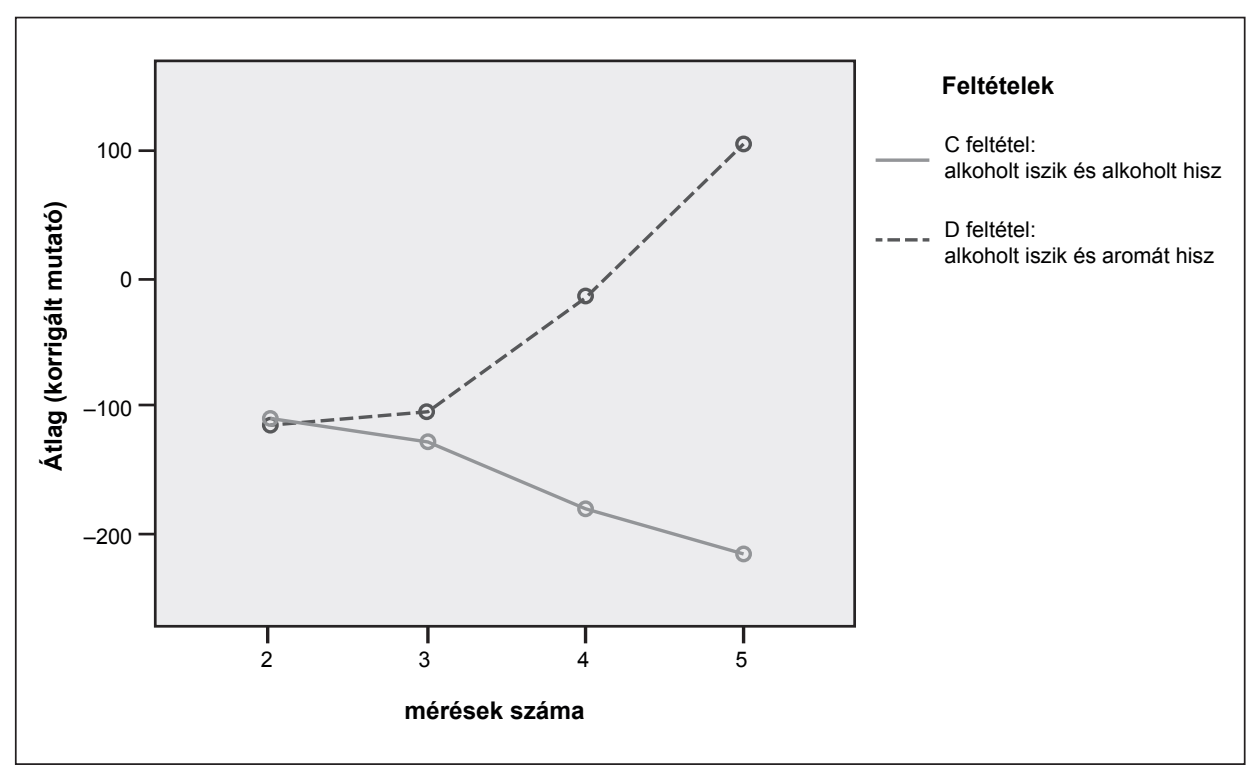

12. ábra. Az alkoholt ivó megtévesztett és helyesen informált résztvevők eredményeinek ábrázolása a testi tünetek faktor mentén

\section{Következtetések}

Jelen vizsgálat a placebohatás mechanizmusát vizsgálja az alkoholfogyasztás kapcsán, specifikusan azt, hogy az alkohol, illetve a placebóként használt aroma elfogyasztása milyen változásokat idéz eló a memória, az egyensúlyérzékelés és a testi-lelki állapot szubjektív megítélése mentén társas, illetve egyéni fogyasztás esetén.

A vizsgálatban sikerült kimutatni a klasszikus placebohatást; az alkoholt és az aromát fogyasztó résztvevók eredményei együttesen mozognak abban az esetben, ha nem tudják, hogy placebót is fogyaszthatnak mind egyéni, mind pedig csoportos helyzetben.

Jelen vizsgálatban további fontos kérdést jelentett a csoportmechanizmusok szerepének tisztázása a placebohatás kialakulásában. Az egyéni és csoportos feltételek összehasonlítása során megállapítható, hogy függetlenül attól, hogy a résztvevők aromát vagy alkoholt fogyasztanak, a csoporthatásoknak erősebb befolyásoló ereje van az eredményekre, mint az elfogyasztott ital alkoholtartalmának.

Eróteljes kompenzációs hatás figyelhetó meg a kísérleti instrukció manipulálása mentén, amelyet a csoporthatások tovább erősítenek. A kísérlet során elfogyasztott mennyiség és a koktélok között eltelt rövid idő nem indokolja a részegség testi tüneteinek megjelenését, a csupán aromát fogyasztók esetében pedig ezen tünetek indokolatlanok, mégis a testi tünetekkel kap- 
csolatos erős sztereotípiáink hatására akkor is „kreálnak” maguknak ilyen tüneteket, amikor azt hiszik, hogy alkoholt ittak. Tehát a részegség testi tünetei sokkal inkább az elvárások által meghatározottak, mint a valós alkoholtartalom által, emellett a sztereotípiák erőteljesebben aktiválódnak csoportos, mint egyéni helyzetben.

Összességében megállapíthatjuk azt, hogy az alkoholfogyasztás mind valós, mind pedig vélt hatásában az etanol fiziológiás, kémiai hatásán túl számos más jellemző vesz részt, amelyek közül elsődlegesen a csoporthatásoknak, továbbá a szuggesztióknak, elvárásoknak van kiemelt szerepe. A placebohatásnak és a társas közegnek köszönhetően tehát az alkohol fogyasztásának tudatában „elveszíthetjük a fejünket”, akár van rá „valódi” okunk, akár nincs. Szociális közegben pedig úgy túnik, hogy az emberek, akár ok nélkül is, hajlamosak elveszíteni a fejüket, és átadni magukat az alkohol elvárt hatásainak. Jelen kutatás jó kiinduló alapot jelenthet a kifejezetten társas közegben, szórakozóhelyeken, bulikban történő, kiemelten a fiatalokat érintő alkoholfogyasztás motivációinak beazonosításához, a fiatalok körében történő alkoholfogyasztással kapcsolatos elvárások nemi és kulturális hatásainak felderítésében. Hosszabb távon, a területen történó további kutatások hozzájárulhatnak akár a (fiatalkori) alkoholizmus és az excesszív alkoholfogyasztás csökkentéséhez. Értékes cél továbbá a sokak által „kívánatosnak" tartott bódult állapot átkeretezése, pl. csökkentett alkoholtartalmú italok (Lachenmeier és mtsai, 2016; Segal \& Stockwell, 2009) vagy „,biztonságosabb italok" (Nutt, 2006) forgalmazása, illetve annak tudatosítása, hogy tudományosan is bizonyítható módon, a szórakozáshoz legalább anynyi szükség van a barátainkra és az agyunkra, mint a kezünkben lévő italra, az elóbbiek használata pedig jóval kívánatosabb, vonzóbb és veszélytelenebb, mint az utóbbié.

\section{6. Általánosíthatóság, a kutatás korlátai}

Jelen vizsgálatban egészséges, alkoholproblémával, illetve -érzékenységgel nem rendelkező, fiatal populáció vett részt, akik önként jelentkeztek az egyetemeken és a közösségi médiában meghirdetett kísérletre. A kísérleti személyek ezen jellemzői a széleskörú általánosíthatóságot erősen korlátozzák.

A vizsgált populációban jelenlévő sztereotípiák, elvárások, tapasztalatok az alkoholhoz való hozzáállás és a fizikai reakciók is eltérhetnek más populációk ezen jellemzőitől. A fiatal közegen kívül érdemes szélesebb körú fogalmi eltérésekkel is számolni: a résztvevők nagy része budapesti lakos, illetve minden résztvevőnk magyar nemzetiségú. Mind a nagyvárosi szokásoknak, mind pedig a magyar kultúrának jelentős befolyása lehet az 
alkohollal kapcsolatos attitúdökre; amelyek lévén, hogy placebo kísérletet végeztünk, ahol az elvárások központi jelentőségúek; az attitúdökön keresztül hatással lehetnek az eredményeinkre. A vizsgálat általánosításakor tehát figyelembe kell vennünk a vizsgált minta szociodemográfiai jellemzőit és alkoholfogyasztási történetét, amelyek hatással lehetnek az alkohollal kapcsolatos elvárásokra, így közvetve az eredményeinkre is. Ezen említett korlát viszonylagos kontrollálása érdekében igyekeztünk minél több információt nyújtani a vizsgált minta szociodemográfiai jellemzőiről, annak érdekében, hogy értelmezésekor pontosabb képet kapjunk és a lehetó legkevesebb torzított általánosítással közöljük az eredményeinket.

A kísérlet menete esetében igyekeztünk a lehetó legpontosabban igazodni a Nagy (2008) vizsgálatában leírtakhoz, azonban valószínúsíthetóen a két vizsgálat, minden igyekezet ellenére, nem nézett ki teljesen ugyanúgy. Annak ellenére, hogy nincs tudomásunk jelentős eltérésről, a kísérletvezetők különböző személye, az instrukció esetleges eltérő megfogalmazása, a vizsgálatvezetők elvárásainak eltérései és más esetleges eltérések a vizsgálatok között, befolyásolhatták és torzíthatták az eredményeket.

\section{Irodalom}

Bárdos, Gy. (2011). Mindennapi placebóink. Magyar Tudomány, 172(3), 276-284.

Barnes, H.M., McCreanor, T., Goodwin, I., Lyons, A., Griffin, C., \& Hutton, F. (2015). Alcohol and social media: drinking and drunkenness while online. Critical Public Health, 26(1), 62-76.

Christiansen, B.A., Goldman, M.S., \& Inn, A. (1982). Development of alcohol-related expectancies in adolescents: Separating pharmacological from social-learning influences. Journal of Consulting and Clinical Psychology, 50(3), 336-344.

Connors, G.J., \& Maisto, S.A. (1979). Effects of alcohol, instructions, and consumption rate on affect and physiological sensations. Psychopharmacology, 62(3), 261-266.

Cziboly, Á., \& Bárdos, Gy. (2003). A placebo fogalma, története, alkalmazása, valamint számos magyarázó elméletének áttekintése. Magyar Pszichológiai Szemle, 58(3), 381-416.

Dúll, A., Varga, K., \& Gősiné Greguss A. (1992). Âltalános pszichológiai gyakorlatok I. Budapest: Nemzeti Tankönyvkiadó

Fillmore, M.T., Mulvihill, L.E., \& Vogel, S.M. (1994). The expected drug and its expected effect interact to determine placebo responses to alcohol and caffeine. Psychopharmacology, 115(3), 383-388.

Fillmore, M.T., \& Vogel, S.M. (1996). Evidence that expectancies mediate behavioral impairment under alcohol. Journal of Studies on Alcohol and Drugs, 57(6), 598-603.

French, M.T., Balsa, A., Homer, J., \& Norton, E. (2011). Alcohol use and popularity: social payoffs from conforming to peers' behavior. The Journal of Research on Adolescence, 21(3), 559-568.

Geusens, F., \& Beullens, K. (2016). Predicting public and private alcohol-related displays on social media: The role of own and friends' drinking behavior. Leuven School for Mass Communication Research Conference Proceedings. Letöltve: 2017. 05. 01-jén: https:/ / lirias. kuleuven.be/handle/123456789/519217 
Gundersen, H., Specht, K., Grüner, R., Ersland, R., \& Hugdahl, K. (2008). Separating the effects of alcohol and expectancy on brain activation: an fMRI working memory study. Neuroimage, 42(4), 1587-1596.

Kirkpatrick, M.G., \& Wit, H. (2013). In the company of others: social factors alter acute alcohol effects. Psychopharmacology, 230(2), 215-226.

Köteles, F. (2014). A placebo-válasz. Budapest: Medicina Kiadó

Lachenmeier, D.W., Pflaum, T., Nieborowsky, A., Mayer, S., \& Rehm, J. (2016). Alcohol-free spirits as novel alcohol placebo - A viable approach to reduce alcohol-related harms? International Journal of Drug Policy, 32(2016), 1-2.

Marlatt, G.A., \& Rosenhow, D.J. (1980). Cognitive processes in alcohol use: Expectancy and the balanced placebo design. In Mello, N.K. (ed.) Advances in Substance Abuse. Behavioral and Biological Research, 80(1), 159-199. Greenwich: JAI Press

Marlatt, G.A., \& Rosenhow, D.J. (1981). The balanced placebo design: methodological considerations. Addictive Behaviors, 6(2), 107-122.

Morean, M.E., \& Corbin, W.R. (2010). Subjective response to alcohol: a critical review of the literature. Alcoholism, Clinical and Experimental Research, 34(3), 385-395.

Nagy, K. (2008). Placebo az alkohol hatásában. Szakdolgozat. Eötvös Loránd Tudományegyetem: Budapest

Nagy, K. Cziboly, Á., Birtalan, L., Bárdos, Gy. (2005). Ethanol or etalon? Placebo effect during alcohol consumption. Clinical Neuroscience, 58(S1), 70.

Nagy, K., Cziboly, Á., \& Bárdos, Gy. (2007). Placebo and the effect of alcohol: to know or not to know? Clinical Neuroscience, 60(S1), 77.

Nutt, D.J. (2006). Alcohol alternatives: A goal for psychopharmacology? Journal of Psychopharmacology, 20(3), 318-320.

Ross, M., \& Olson, J.M. (1981). An expectancy attribution model of the effects of placebos. Psychological Review, 88(5), 408-437.

Scalese, M., Denoth, F., Siciliano, V., Bastiani, L., Cotichini, R., Cutilli, et al. (2017). Energy drink and alcohol mixed energy drink use among high school adolescents: Association with risk taking behavior, social characteristics. Addictive Behaviors, 72 93-99.

Schlauch, R.C., Waesche, M.C., Riccardi, C.J., Donohue, K.F., Blagg, C.O., Christensen, R.L., et al. (2010). A meta-analysis of the effectiveness of placebo manipulations in alcoholchallenge studies. Psychology of Addictive Behaviors, 24(2), 239-253.

Scott-Sheldon, L.A.J., Carey, K.B., Cunningham, K., Johnson, B.T., Carey, M.P., \& The MASH Research Team (2016). Alcohol use predicts sexual decision-making: A systematic review and meta-analysis of the experimental literature. AIDS and Behavior, 20(S1), 19-39.

Segal, D.S., \& Stockwell, T. (2009). Low alcohol alternatives: a promising strategy for reducing alcohol related harm. International Journal of Drug Policy, 20(2), 183-187.

Shapiro, A.K., \& Shapiro, E. (1997). The powerful placebo. From ancient priest to modern psychician. Baltimore: Johns Hopkins University Press

Tyler, K.A., Schmitz, R.M., Adams, S.A., Simons, L.G. (2016). Social factors, alcohol expectancy, and drinking behavior: A comparison of two college campuses. Journal of Substance Use, 22(4), 357-364.

Vuchinich, R.E., Tucker, J.A., \& Sobell, M.B. (1979). Alcohol, expectancy, cognitive labeling, and mirth. Journal of Abnormal Psychology, 88(6), 641-651.

Webster's (1997). Webster's Universal College Dictionary. New York: Random House 


\title{
Köszönetnyilvánítás
}

A kutatás fedezetét a K109549 számú OTKA pályázat biztosította.

\section{Szerzői munkamegosztás}

Bodnár Vivien: elméleti áttekintés, kutatás megtervezése és lebonyolítása, hipotézisek kidolgozása, vizsgálatok végzése, adatgyújtés és adatelemzés lefolytatása, a statisztikai elemzések és faktoranalízis, eredmények értelmezése, kézirat szövegezése. Bárdos György: elméleti áttekintés, statisztikai számítások, az eredmények értelmezése, a kézirat szövegezése. Nagy Krisztina: elméleti áttekintés, mérőeszközök kialakítása és validálása, adatgyújtés megtervezése és lebonyolítása, vizsgálatok végzése. Cziboly Ádám: elméleti áttekintés, vizsgálatok végzése, eredmények értelmezése.

\section{Nyilatkozat érdekütközésról}

A szerzők ezúton kijelentik, hogy esetükben nem állnak fenn érdekütközések.

\section{The Placebo Effect and the Alcohol}

\author{
BODNÁR, VIVIEN - NAGY, KRISZTINA - CZIBOLY, ÁDÁM - \\ BÁRDOS, GYÖRGY
}

Theoretical background: The placebo effect can be detected in many instances during our life, when an expectation associated with any psychoactive material leads to subjective and physiological changes. Aims: The present work has studied the role of ethanol and of the expectancies associated with the alcohol in the changes of the behaviour, especially of the memory, of the balance and of the subjective state in participants consuming alcoholic, alcohol-suggested, or non-alcoholic cocktails. Methods: Using a balanced-placebo design in individual or social situations, respectively, we examined changes of the short term memory, of the balance and of subjective body-mental feelings by testing recalling of wordlists, by keeping the "drunken stance" and by applying a visual analogue scale of 17 pairs of statements. Results: When recording body-mind conditions, the examined groups have shown different patterns along the Social (eigenvalue: $5.25, \mathrm{R}^{2}=30.9 \%$ ) as well as Body Symptoms (eigenvalue: $2.77, \mathrm{R}^{2}=47.2 \%$ ) factors. Participants reported subjective symptoms corresponding to their expectations initiated by the manipulations, which were further enhanced by the group effect. We have managed to show the expectations induced classical placebo-effect in both the individual and the social situations in the deceived participants 
who actually had not consumed alcohol. The groups consuming alcohol or placebo, respectively were not different from each other either in their social behaviour, or somatic symptoms, or the balance. Consuming alcohol in groups further enhances the true effect of alcohol on memory as well as the putative effect of (non) alcohol consumption on. Conclusions: When consuming only small amount of alcohol, the alcohol itself has only a minor effect on the subsequent behaviour. Most of the resulting psychological and physical consequences can be, in fact, due to the placebo effect determined by expectations and by the social environment.

Keywords: alcohol, placebo, balanced placebo design, expectancy, social impact 